\title{
Alman Hukuku Uygulamaları Işı̆̆ında Covid-19 Önlemlerinin İşyeri Kira Sözleşmeleri Bakımından Sonuçları
}

\author{
Results of Covid-19 Precautions in the Light of German Law Practices in \\ terms of Lease Contracts of Commercial Premises
}

Çiğdem İleri, LL.M. ${ }^{* *}$ (iD

\section{öz}

Covid-19 (yeni tip koronavirüs) salgını, hayatın her alanında olduğu gibi hukuki ve ekonomik açıdan ciddi sonuçlar doğurmaktadır. Salgınla mücadele kapsamında alınan kamusal önlemlerin bilhassa işyeri kira sözleşmeleri ve kira bedelini ödeme borcu altındaki kiracı bakımından hangi sonuçları doğuracağı, kısıtlama ve yasaklamalar dolayısıyla bozulan sözleşmedeki menfaat dengesinin hangi hukuki araçlarla yeniden sağlanabileceği bakımından çeşitli görüşler ileri sürülmekle beraber bunlar arasında en çok sözleşmenin değişen koşullara uyarlanması talebi ile imkansızlık ve kiralananın ayıplı hale geldiği iddiası gündeme gelmektedir. Konuyla ilgili olarak Almanya’da yürürlüğe giren yasal karine ve mazisi uzun bir geçmişe dayanan emsal yargı kararları da Türk hukuku bakımından yol gösterici olabilecek niteliktedir. Bu kapsamda; aşağıdaki çalışmada, Alman hukukundaki yasal düzenlemeler ile konuya ilişkin yargı kararları ve öğreti görüşleri sunulacak, akabinde mesele Türk hukuku açısından ele alınarak işyeri kira sözleşmelerinin akıbeti bakımından bir değerlendirme yapılacaktır.

Anahtar Kelimeler: Covid-19 salgını, Koronavirüs, İşyeri Kira Sözleşmeleri, İmkânsızlık, Sözleşmenin Değişen Koşullara Uyarlanması, Ayıp

\section{ABSTRACT}

The Covid-19 (new type of coronavirus) epidemic has serious legal and economic consequences, as in all areas of life. Various opinions have been put forward regarding the consequences of the public measures taken within the scope of the fight against the epidemic, especially for the lease contracts of commercial premises, and with which legal instruments the balance of interest can be restored due to restrictions and prohibitions. Among these, the most common claims are the demands of adapting the contract to changing conditions, the claim of impossibility, and the claim that the rented property has become defective. Regarding the subject, the new legal presumption, and precedent judgments in Germany, which have a long history, can also be guiding in terms of Turkish law. In the following study, current legal regulations in German law, judicial decisions and opinions on the subject will be presented, and then the issue will be discussed in terms of Turkish law and an evaluation will be made in terms of the fate of rental contracts.

Keywords: Covid-19 Pandemic, Coronavirus, Lease Contracts of Commercial Premises, Impossibility, Adaptation of Contracts, Defect

* Avukat, Bucerius Law School Hamburg Özel Hukuk Doktora Öğrencisi

Sorumlu Yazar/Correspondence Author: Çiğdem İleri

E-posta/E-mail: cigdemileri2@gmail.com

Geliş Tarihi/Received: $\quad 31.03 .2021$

Kabul Tarihi/Accepted: $\quad 22.05 .2021$ 


\section{Giriş}

Covid-19 pandemisi ${ }^{1}$ dolayısıyla İçişleri Bakanlığı tarafından yayımlanan genelgeler ile alınan önlemler uyarınca tüm restoranların, barların, gece kulüplerinin ve benzer nitelikteki işletmelerin kapatılmasına ilişkin yasak neticesinde işletme sahiplerinin işyeri kiralarını ödemeye devam edip etmeyecekleri bu kapsamda akla gelen ilk hukuki sorulardan biri olmuştur. İşyerlerinin kapalı olmasına rağmen kira bedelinin eksiksiz şekilde ödenmesine, ilk bakışta, herhangi teorik ya da teknik bir bilgiye başvurmadan adalet duygusuyla bağdaşmadığından bahisle de karşı çıkılabilir. Bununla birlikte bu durumun (karantinalar ve kapanmalar döneminde hiç çalışmayan ya da sınırlı şekilde çalışan işyerlerinin kiralarının eksik ödenmesi ya da hiç ödenmemesinin) hukuki gerekçeleri aşağıda açıklanacaktır.

İlk olarak, salgın dolayısıyla alınan önlemlerin işyeri kira sözleşmeleri bakımından (geçici) imkânsızlık teşkil edip etmeyeceği tespit edilerek bu kuruma bağlanan sonuçlar değerlendirilmelidir.

Türk Borçlar Kanunu’nun (TBK) 299. maddesine göre; kiracı kararlaştırılan kira bedelini ödemekle, kiraya veren ise 301. madde uyarınca kiralananı kira süresi boyunca kullanıma (sözleşmede öngörülen kullanım amacına) uygun bulundurmakla yükümlüdür. Bu yükümlülük hem kira konusu eşyanın sözleşmede öngörülen kullanım amacına uygun şekilde kiracıya teslim edilmesini hem de kira süreci boyunca kiralananı kullanıma uygun bulundurma borcunu kapsamaktadır. Pandemi ile mücadele kapsamında alınan önlemler dolayısıyla kapatılan işyerleri bakımından da kiralananın sözleşmeden öngörülen kullanım amacına uygun şekilde işletilemediğinden bahisle kiralanan işyerinin (kira konusunun), ayıplı hale geldiğinden söz edilmesi kural olarak mümkündür.

Bir diğer tarafta, işlem temelinin çökmesi dolayısıyla - bir diğer ifadeyle TBK’nın 138. maddesinin ilk fıkrası uyarınca sözleşmenin yapıldığı sırada taraflarca öngörülmeyen ve öngörülmesi de beklenmeyen olağanüstü bir durum, borçludan kaynaklanmayan bir sebeple ortaya çıkar ve sözleşmenin yapıldığı sırada mevcut olguları, kendisinden ifanın istenmesini dürüstlük kurallarına aykırı düşecek derecede borçlu aleyhine değişirse - sözleşmenin değişen koşullara uyarlanması gündeme gelebilecektir. Salgın nedeniyle işyerlerinin aylarca kapanması karşısında kiracıların kiranın tamamını aralıksız olarak ödemeye devam edip etmeyeceği sorusuna bu bağlamda bir cevap aranmalıdır çünkü sözleşmenin yapıldığı sıradaki olgular dürüstlük kurallarına aykırı düşecek derecede borçlu kiracı aleyhine değişmiş olmaktadır. Salgın hastalığın yarattığı koşullar; sözleşmenin yapıldığı sırada, taraflarca öngörülmeyen ve öngörülmesi de beklenmeyen olağanüstü ve günlük hayatın olağan akışına uymayan olgu ve olaylardır. Böylesi bir durumda kanunun işlem temelinin çökmesi haline ilişkin olarak öngördüğü en hakkaniyetli çözüm, sözleşmenin değişen koşullara uyarlanması ve bu kapsamda kira bedelinde indirim yapılması olacaktır.

1 Koronavirüs (COVID-19) Çin'in Vuhan Eyaleti’nde Aralık 2019 sonlarında solunum yolu sıkıntıları gelişen bir grup hastada yapılan araştırmalar sonucunda 13 Ocak 2020'de tanımlanan bir virüs olup virüsün hızla tüm dünyaya yayılması ve küresel çapta salgın haline gelmesi akabinde Dünya Sağlık Örgütü (WHO) tarafından 11.03.2020 tarihinde pandemi ilan edilmiştir. Bkz. https://www.who.int/director-general/speeches/detail/who-director-general-s-opening-remarks-atthe-media-briefing-on-Covid-19_-11-march-2020 (Son Erişim Tarihi: 25 Mart 2021) 


\section{ALMAN HUKUKU UYGULAMALARI}

\section{A. GENEL OLARAK}

2020 yılının bahar aylarında alınan pandemi önlemleri dolayısıyla kira hukuku alanında kiracı ve kiraya verenler arasında yaşanan hukuki açmazlar nedeniyle Almanya'da bu sorunların bir daha yaşanmaması adına bir çözüm arayışına girilmiştir. Meselenin özü kira ödemelerine ilişkin riskin kimin tarafından üstlenileceği olup kiracılar tarafından; özellikle Alman Medeni Kanunu'nun 313. maddesi uyarınca işlem temelinin çökmesi, kiralananın ayıplı hale gelmesi gibi çeşitli hukuki kurumlar ileri sürülmektedir. Kiraya verenler tarafında ise genellikle ortaya çıkan riskin kiracı tarafından üstlenilmesi gerektiği savunulmaktadır.

Aşağıda öncelikle kiracıların taleplerinin temel dayanağını oluşturan kamusal önlemler dolayısıyla kiralananın ayıplı hale geldiği iddiasına ilişkin olarak bu hususta Alman hukukundaki ilgili düzenleme ve görüşler sunulacak, akabinde söz konusu kamusal yasakların işyeri kira sözleşmeleri bakımından işlem temelinin çökmesine yol açacağına ilişkin kanunda öngörülen yeni yasal karine ve konuya ilişkin yargı kararlarından bahsedilecektir.

\section{B. KIRALANIN AYIPLI HALE GELMESI DOLAYISIYLA KIRA BEDELINDE INDIRIM TALEBI (MIETMINDERUNG)}

Alman Medeni Kanunu'nun (BGB) 536. maddesinin 1. fikrasına göre; kiralananın kiracıya teslimi anında sözleşmede öngörülen kullanım amacını önemli ölçüde azaltacak ya da ortadan kaldıracak şekilde ayıplı olması ya da söz konusu ayıbın kira süresi boyunca ortaya çıkması durumunda kiracı, kira bedelinde indirim yapılmasını talep edebilecektir.

Sübjektif ayıp tanımına göre, kiralananın sözleşmede kararlaştırılan nitelikleri taşımaması durumunda kiralananın ayıplı hale geldiği kabul edilmektedir. ${ }^{2}$ Bir diğer ifadeyle; kiralananın ayıplı olup olmadığının tespitinde esas alınacak ilk kıstas, kiralananın taşıması gereken özelliklere ilişkin sözleşmede yer alan düzenlemelerdir. ${ }^{3}$ Sözleşmede kiralananın niteliğine ilişkin bir düzenleme bulunmuyorsa, bu durumda sözleşmede kararlaştırılan kullanım amacı ve (BGB 242. maddesi uyarınca) dürüstlük kuralı nazara alınarak kiralananın kullanım amacına uygun olup olmadığı ve dolayısıyla ayıplı olup olmadığı tespit edilecektir. ${ }^{4}$ Bu bağlamda, - işyeri kiralamaları bakımından - belirli koşullar altında bir alışveriş merkezinde müşteriye erişebilirliğin kiralananın niteliğine ilişkin bir anlaşma teşkil edip etmediğinin ve dolayısıyla getirilen kapatma önlemleri ve kontak sınırlamalarının kiralananı bu kapsamda ayıplı hale getirip getirmediğinin tespit edilmesi gerekir. ${ }^{5}$

2 Norbert Eisenschmid, Schmidt-Futterer Mietrecht Kommentar, 14. Auflage 2019, Hrsg. Hubert Blank, $\$ 536$ Rn. 19 ; Martin Häublein, Münchener Kommentar zum Bürgerlichen Gesetzbuch: BGB, Band 5: Schuldrecht - Besonderer Teil II, 8. Auflage 2020, Hrsg. Franz Jürgen Säcker, Roland Rixecker, Hartmut Oetker, Bettina Limperg, $₫ 536$ Rn. 3; BGH NZM 2013, 184 - Straßenbaulärm im Mietverhältnis in „Innenstadtlage“.

5 Stefan Sentek/ Carsten Ludley, “COVID-19: Die hoheitlich verfügte Ladenschließung als Mietmangel”, NZM 2020 , s. 407. 
Uygulamada akdedilen işyeri kira sözleşmelerinde, kiralanan işyerinin - özellikle kiracının müşterileri için fiili erişilebilirliği veya müşteri iletişimi gibi - belirli (fiziksel) özellikleriyle ilgili saptamalar genellikle yer almaz. ${ }^{6}$ Bunun yerine sözleşme tarafları genellikle sözleşmede işyerinin kullanım amacını ("kiralama amacı", "amaç" veya "kullanım amacı" başlığı altında) açıkça belirlemektedirler.7 Öte yandan öğretide, sözleşmede kararlaştırılan kullanım amacının işyeri kiraları bakımından büyük önem arz ettiği, bunun BGB'nin 535. maddesinin 1. fikrasının 2. cümlesi uyarınca "sözleşmeye dayalı kullanım amacı ve durumu"nu tespit ettiği ileri sürülmektedir. ${ }^{8}$ Buna göre, taraflar sözleşmede kiralanan işyerinin taşıyacağı özellikleri belirlememişlerse sözleşmeye uygunluk meselesi, işyerinin sözleşmeye bağlı olarak kararlaştırılan kullanım amacına tamamen uygun bir durumda olup olmadığına göre belirlenecektir. ${ }^{9}$

$\mathrm{Bu}$ bağlamda örneğin bir alışveriş merkezinde faaliyet gösteren bir işyerinin çok sayıda müşteri tarafından erişilebilir olması ve sadece bu amaçla ziyaret edilmesi beklenir bir durumdur. ${ }^{10}$ Kiralanan yerin çekiciliği ve buna bağlı olarak kira bedeli de esasen buna göre belirlenmektedir. ${ }^{11}$ Merkezi bir alışveriş meydanında bulunan işyeri de, çekiciliğini çok fazla yaya trafiğinin ve muhtemelen aynı zamanda araba trafiğinin yoğun ve dolayısıyla müşteri sirkülasyonunun fazla olması gerçeğinden kazanır. ${ }^{12}$ Bu özellikler, bir mağazanın böyle bir konumdaki kullanıma elverişliliğini doğrudan belirlemektedir. Bahsi geçen niteliklerin ve kiralanan işyerinin kullanıma uygunluğunun, doğrudan doğruya hem mekânsal olarak hem de nedensellik açısından etkilendiği açıktır. ${ }^{13}$

Ayıp kavramı ile kanun koyucu tarafından kastedilenin öncelikli olarak kiralanan mülkün kendisiyle doğrudan ilgili koşullar - örneğin kiralananın kullanımı doğrudan bozan ve etkileyen yapısal hatalar - olduğu ileri sürülmektedir. ${ }^{14}$ Bir diğer ifadeyle, kiraya verenin kiralanan mülkün fiziksel durumuna ilişkin riskini ${ }^{15}$ kiracının ise kiralananın kullanım riskini üstlendiği kabul edilmektedir. ${ }^{16}$ Öte yandan, Alman Federal Mahkemesi (önceki adıyla Reichsgericht), "dans lokali" davasından ${ }^{17}$ bu yana, kanunda öngörülen maddi ayıp kavramının bazı münferit durumlarda oldukça dar kapsamlı kaldığını, somut olayın şartlarına göre ayıp tanımının kiralananın dışındaki - ancak kiralanan mülkün kullanımını etkileyen, kısıtlayan veya imkansız hale getiren - koşullara da genişletilmesi gerektiğini halihazırda uzun yıllardır kabul etmiş durumdadır. ${ }^{18}$

\footnotetext{
Sentek/ Ludley, s. 407.

Peter Günter, Gewerberaummiete Kommentar, 2. Auflage 2019, Hrsg. Hartmut Guhling, Peter Günter, $\$ 536$ Rn. 74 vd.

Günter, $\$ 536$ Rn. 75.

BGH NZM 2004, s. 736.

10 Sentek/ Ludley, s. 407.

11 Sentek/ Ludley, s. 407.

12 OLG Dresden NZM 1999, s. 317.

13 Peter Kluth/ Julius Böckmann, Zugangsbeeinträchtigung aufgrund staatlicher Baumaßnahmen - Risikoverteilung bei Gewerberaummiete NZM 2003, s. 882; OLG Dresden NZM 1999, s. 317.

14 Walter Weidenkaff, Palandt Kommentar zum BGB, 78. Auflage 2018, Hrsg. Otto Palandt, §536 Rn. 16; Jan Hellner, "Pacta sunt servanda - gilt dieser Grundsatz auch für die Miete in Zeiten der COVID-Pandemie?”, NJOZ 2020, s. 770.

15 Peter Günter, "Der Einfluss öffentlich-rechtlicher Verpflichtungen auf mietvertragliche Vereinbarungen", NZM 2016, s. 569; Sentek/Ludley, s. 407-410.

16 Donata Zehner, "Mietrechtliche Neuregelungen in Zeiten der Coronakrise", JA 2020, s. 489.

17 RGZ 87, 277 - III 145/15. Ayrıntılı bilgi için bkz. I.D. bölümü s. 12 vd.

18 Hellner, s. 770. Öğreti ve yargı kararlarında çevresel ayıp olarak nitelendirilen bu ayıp türü ve çevresel ayıba karşı kiraya
} 
Alman Federal Mahkemesi’nin ünlü Bolzplatzkararına göre; kiracı, kira sözleşmesi sürdüğü müddetçe, sözleşmenin başındaki mevcut çevresel koşulların sözleşmenin devamı boyunca aynı şekilde kalacağını bekleyemez. ${ }^{19}$ Böylesi bir beklenti, yalnızca özel istisnai durumlarda ve her durumda böyle bir anlaşmanın kabulüne ilişkin somut kanıtlar varsa dikkate alınacaktır. ${ }^{20}$ Bu nedenle, işyeri kiraları bakımından müşteri erişilebilirliği konusu, kira sözleşmesinin akdedilmesinden önce her iki tarafça da tartışılmış olmalı ve kiraya veren, kiracının müşteri hacmine ilişkin talebini açık ya da zımni şekilde onaylamış olmalıdır. ${ }^{21}$ En nihayetinde bir işyeri kira sözleşmesi bakımında kiralanana ilişkin bir "müşteri erişimi” özelliği açık ya da zımni şekilde kararlaştırılmışsa, alınan kamusal önlemlerin mevcut olduğu ve kiralananı etkilediği ölçüde BGB’nin 536. maddesi uyarınca onu ayıplı hale getireceği ileri sürülebilir. Öğretide bu kapsamda, kiralananın konumu ve özellikleriyle ilgili olan koşulların, kamu hukukundan doğan sınırlamalar dolayısıyla etkilenebileceğinden bahisle kiralananın ayıplı hale geleceği kabul edilmektedir. ${ }^{22}$ Bir diğer ifadeyle; kanunun, kiralanandaki ayıbın mutlak surette kiralananın fiziksel koşullarından kaynaklanmasını şart koşmadığı, çünkü böylesi bir sınırlamanın kiracının menfaatleri ile örtüşmeyeceği ve bunu büyük ölçüde daraltacağg belirtilmektedir. ${ }^{23}$

Bir diğer taraftan ise Alman Hukuku’nda kiralanan taşınmazın doğal afetler nedeniyle maruz kaldığ zararlar bakımından, kiraya verenin bunlara karşı önlem alıp almadığına veya almak zorunda olup olmadığına bakılmaksızın, BGB’nin 536. maddesi anlamında ayıptan söz edileceği kabul edilmektedir ${ }^{24}$ ki Alman Virolog Christian Drosten, Covid-19 salgınını "ağır çekimde gerçekleşen bir doğal afet" olarak nitelendirmektedir. ${ }^{25}$ Covid-19 salgınının da kiralık işyerini etkileyen bir doğal afet olarak değerlendirilebileceği, çünkü olağanüstü bir acil durum olarak nitelendirilse bile, bu durumun doğal afetin etki ve sonuçları ile bir tutulabileceği ifade edilmektedir. ${ }^{26}$

Covid-19 salgınının (kapatmalar, kontak ve çıkış kısıtlamaları) bir sonucu olarak öngörülen kamusal kısıtlamalar, kiracının kişisel ve operasyonel koşullarıyla bağlantılı olmayıp öncelikli olarak "sistem açısından kritik bir altyapı" sağlamayı ve virüsün daha fazla yayılmasını önlemeyi amaçlamaktadır. ${ }^{27}$ Bununla birlikte - her ne kadar işyeri kapatmaları ve sokağa çıkış kısıtlamaları münferit bir kiracıya yönelik olmasa da-, mevcut kamusal önlemler ile kiralananın kullanılabilirliğinin etkilendiği ve

verenin sorumluluğu bakımından ayrıntılı inceleme için bkz. Çiğdem İleri, "Çevresel Gürültü Nedeniyle Kiraya Verenin Ayıba Karşı Tekeffül Sorumluluğu”, Ylldırım Beyazıt Hukuk Dergisi, Sayı: 1, Ocak 2021, s. 461 vd.

BGH, Urt. v. 29.04.2015 - VIII ZR 197/14, NJW 2015, s. 2179.

20 BGHZ 205, 177, NZM 2015, 481.

21 Sentek/ Ludley, s. 408.

22 Günter, s. 570; BGH NJW-RR 2014, 264 (265); Häublein, § 536 Rn. 25; Alexander Schall, “Corona-Krise: Unmöglichkeit und Wegfall der Geschäftsgrundlage bei gewerblichen Miet - und Pachtverträgen”, JZ 2020, s. 388; Hubert Schmidt, COVID-19: Rechtsfragen zur Corona-Krise, 2. Baskı 2020, \$ 3 Rn. 71; Hans-Michael Krepold, "Gewerbemietverträge in Zeiten der Corona-Pandemie", WM 2020, s. 728-734.

23 Arnold Lehmann-Richter, "Einkaufscenter: Beitritt zu Werbegemeinschaftsverein wirksam!", MietRB 2016, s. 196-197; Martin Häublein/ Maximilian Müller, "Wer trägt das Pandemierisiko in der Geschäftsraummiete?", NZM 2020, s. 489.

24 Häublein, $\$ 536$ Rn. 23.

25 https://www.ndr.de/nachrichten/info/coronaskript122.pdf (S. 2)

26 Sentek/ Ludley, s. 409.

27 Sentek/ Ludley, s. 408. 
sözleşmede öngörülen kullanım amacına halel geldiği açıktır. ${ }^{28}$ En nihayetinde öğretide ve yargı kararlarında; kamu hukuku kısıtlamaları ve kullanım engellerinin, kiralanan mülkün özel niteliği, kullanılabilirliği veya konumundan kaynaklanması ve sadece kiracının kişisel veya operasyonel koşullarından kaynaklanmaması durumunda, kiralananın ayıplı olduğu kabul edilmektedir. ${ }^{29}$

\section{KiRACI LEHINE GETiRILEN KANUNi KARINE}

Kira hukuku alanında yaşanan tüm yasal belirsizliklere cevaben ve bunların tekrar ortaya çıkmasını engellemek adına, Federal Meclis (Bundestag) tarafından, 17.12.2020 tarihinde "Borç tasfiye prosedürünün kısaltılması ve şirket, kooperatif, dernek ve vakıflar hukuku ile kira ve patent hukukunda pandemiyle ilgili düzenlemeleri uyarlama hakkında Kanun”30 kabul edilmiştir. Anılan Kanun'da yapılan ve 31 Aralık 2020 tarihinde yürürlüğe giren değişiklik ile Covid-19 salgını dolayısıyla gerçekleştirilen işyeri kapatmalarının kira sözleşmesinin tarafları arasında işlem temelinin çökmesine sebebiyet verdiği ve BGB'nin 313. maddesi bağlamında bunun da sözleşmenin değişen koşullara uyarlanması yoluna kapı araladığı bir kanuni karine olarak kabul edilmiştir. Öte yandan anılan kanun değişikliği uyarınca Covid-19 ile ilgili kira uyarlamaları bakımından başlatılacak yasal işlem ve davalar öncelikli ve ivedi olarak görülecektir. Bununla birlikte Kanun, işyeri kapatmalarına ilişkin kamusal kısıtlamaların BGB’nin 535. maddesi uyarınca ayıp teşkil edip etmediği sorusuna cevap vermemektedir.

Kanun koyucu, Alman Medeni Kanunu’nu Düzenleyici Kanun'un 240. maddesine yeni bir fikra ekleyerek (\$ 7) BGB’nin 313. maddesi (sözleşme koşullarının değişmesi) bakımından işyeri kiralarına ilişkin olarak bir kanuni karine eklemiş ve buna göre devletçe öngörülen koronavirüs önlemleri ve kısıtlamalarının kira sözleşmesi akdedilmesinden sonra koşulları önemli ölçüde değiștirecek nitelik taşıdığını ve sözleşmenin uyarlanmasına yol açacağı, bu bağlamda da kira bedelinde bir uyarlama yapılabileceği hükme bağlanmıştır.

Anılan hükme göre; konut kiraları dışındaki kiralanan yerler, Covid-19 salgınıyla mücadele bakımından alınan hükümetin önlemleri neticesinde kiracı bakımından işletilemez ya da çok sınırlı şekilde ve üst düzey önlemlerle işletilebilirse, bu durumda işlem temeli çökmüș sayılır ve sözleşmenin yapıldığı sıradaki olguların, kiracıdan ifanın istenmesini dürüstlük kurallarına aykırı düșecek derecede borçlu aleyhine değiştiği kabul edilmektedir.

Yeni yasal düzenleme ile Covid-19 salgınıyla mücadele kapsamında alınan bir kamusal önlemin kira ilişkisinin tarafları arasında sözleşme temelinde ciddi bir değişikliğe yol açacağı hususunda kiracı lehine bir adi karine öngörülmüş durumdadır. Bununla birlikte, bu karine yalnızca kiralama konusu

28 Sentek/ Ludley, s. 408.

29 Sentek/ Ludley, s. 408; BGH NZM 2014, s. 166.

30 „Gesetz zur weiteren Verkürzung des Restschuldbefreiungsverfahrens und zur Anpassung pandemiebedingter Vorschriften im Gesellschafts-, Genossenschafts-, Vereins - und Stiftungsrecht sowie im Miet - und Patentrecht" Bundestag Drucksache 19/25251 - („Gesetzesänderung“), http://dipbt.bundestag.de/extrakt/ba/WP19/2656/265684. html (Son Erişim Tarihi: 13.03.2021) 
işyeri artık kiracı bakımından kullanılamaz hale gelmişse veya yalnızca kamusal önlemler dolayısıyla ancak ciddi/ önemli kısıtlamalarla işletilebiliyorsa geçerlidir.

Kanun koyucu kural olarak perakende satış alanının yalnızca belirli bir bölümünün kullandırılması veya belirli bir alanda bulunmasına izin verilen kişi sayısının hükümet eliyle sınırlandırılması durumunda önemli bir kısıtlamadan söz edilebileceğini belirtmiştir. Kanun gerekçesine göre; halka açık bir işletmede, tüketim isteğinin azalması nedeniyle müşteri sirkülasyonu azalmışsa bu durumda önemli bir kısıtlama mevcut değildir.

Öte yandan bahsi geçen yasal karine, otomatik olarak sözleşmenin uyarlanması sonucunu doğurmayacaktır. Bir diğer ifadeyle, kiraya verenin yasal karinenin aksini ispat edebileceği ve sözleşmenin uyarlanması yolunun gündeme gelmeyeceği bazı çıkış noktaları mevcuttur. Örneğin; kira sözleşmesi, SARS-CoV-2 koronavirüsün yayılmasının (yeni bir virüs dalgasının) önceden öngörülebilir olduğu bir zamanda akdedilmişse karine geçerli olmayacaktır. Böylesi bir durumda, kural olarak söz konusu kira sözleşmesinin, her iki tarafça ekonomik hayatta kapsamlı ve büyük ölçekli bir değişikliğin süregeldiği bilgisiyle akdedildiği varsayılabilir.

Öte yandan kiracının sözleşmenin uyarlanması yönündeki talebi ancak BGB’nin 313. maddesinde öngörülen uyarlama şartlarının gerçekleşmesi halinde kabul görebilir. Uyuşmazlık halinde kirac1, kamusal önlem dolayısıyla sözleşmenin mevcut haliyle devam etmesinin kendisinden beklenemeyeceğini ortaya koymalı ve ispat etmelidir. Sözleşme şartlarındaki oransızlığın derecesi, esasen kamusal kısıtlamaların kiralanan işyerinin işleyişini ne kadar yoğun şekilde etkilediğine bağlıdır. Kiracının devletten kira desteği aldığı, kısa çalışmanın geçerli olduğu ya da mal alımını durdurarak harcamalardan tasarruf ettiği durumlarda bahsi geçen oransızlığın söz konusu olmayacağı ve uyarlamanın kural olarak gündeme gelmeyeceği kabul edilmelidir. ${ }^{31}$

Kanun koyucu, kanun değişikliğinin BGB’nin 313. maddesinin uygulanabilirliğine ilişkin mevcut belirsizliğin ortadan kaldırılması amacıyla yapıldığını belirtmekte ve işyeri kiralarında kiracının müzakere pozisyonunu güçlendirmeyi amaçlamaktadır.

Tüm bunlara rağmen kanun koyucu, kanun gerekçesinde kira hukuku uyarınca ayıptan doğan seçimlik ya da yenilik doğurucu hakların 313. madde karşısında öncelikli olarak uygulanacağını belirtmiştir. Bu durumu destekler şekilde, güncel içtihatlar da, ayıptan doğan hakların sözleşmenin uyarlanması talebini dışladığını ifade etmektedir.

Özet olarak; pandemi yasakları dolayısıyla faaliyetleri kısıtlanan veya askıya alınan işyeri sahipleri bakımından, işyeri kiralarının indirilmesi talebinin BGB’nin 313. maddesi (sözleşmenin uyarlanması kurumu) kapsamında değerlendirilmesine ilişkin olarak Alman hukukunda yeni bir yasal karine getirilmiştir. Bir diğer ifadeyle, anılan yasa değişikliği ile pandemiyle mücadele kapsamında alınan kamusal önlemlerin sözleşme temelini sarsacağı hususunda kiracı lehine bir adi karine öngörülmüş ve aksini ispat yükü kiraya veren tarafa yüklenmiştir. Bununla birlikte; bahsi geçen yasa değişikliği, kiracıya otomatik olarak sözleşmenin uyarlanması yönünde bir talep hakkı sağlamamaktadır. Aynı

31 Silvio Sittner, “Mietrechtspraxis unter Covid-19”, NJW 2020, s. 1172. 
zamanda kira indiriminin kapsamı, süresi ve oranı da düzenlemede yer almamaktadır. Öte yandan kirac1; 313. maddede öngörülen diğer şartlar bakımından bunların somut olayda gerçekleştiğini bilhassa sözleşmenin mevcut haliyle sözleşmeye devam etmesinin kendisinden beklenemeyeceğini - ispatla mükelleftir.

Sonuç itibariyle; anılan yasal karine ile pandemi önlemlerinin kira sözleşmeleri bakımından hukuki sonuçlarına ilişkin olarak tam anlamıyla bir yasal belirlilik oluşmasa da, en azından kiracının kira bedelinin indirilmesi (uyarlanması) talebinin yasal dayanağı bakımından 313. maddenin de masada olduğu ve şartları oluşmuşsa uygulama alanı bulabileceği anlaşılmıştır. En nihayetinde uyarlama şartlarının mevcudiyeti ve uyarlama yapılacaksa kira bedelinin ne oranda indirileceği somut olay düzeyinde incelenecektir.

\section{EMSAL YARGI KARARLARI}

Anılan yasal düzenleme ile, Alman hukukunda pandeminin başından beri işyeri kapatmalarının kira hukuku alanında doğurduğu hukuki sorunlar ve sonuçlar bakımından eyalet mahkemelerince birbirinden farklı hukuki değerlendirmeler yapılmakta ve bu doğrultuda kararlar verilmektedir. Belirtmek gerekir ki kararlar arasında şu an için bir yeknesaklık bulunmamaktadır.

Heidelberg Eyalet Mahkemesi'nin 30.07.2020 tarihli kararında; ${ }^{32}$ pandemi önlemleri kapsamında işyerlerinin kapatılmasına ilişkin getirilen düzenlemelerin Alman Medeni Kanunu’nun 536. maddesinin 1. fıkrası uyarınca ayıp teşkil etmediği, alınan üstün nitelikli önlemlerin kamuyu koruma amacı taşıdığı ve doğrudan kiralanan mülkün kendisine yönelik olmadığı, yalnızca kiracının işletme faaliyetiyle ilgili bulunduğu kanaatine varılmıştır.

Zweibrücken Eyalet Mahkemesi 11.09.2020 tarihli kararında ${ }^{33}$ ve Wiesbaden Eyalet Mahkemesi de 05.11.2020 tarihli kararında ${ }^{34}$ işyerlerinin kapatılmasına ilişkin alınan önlemlerin kiralananı ayıplı hale getirmediğini, bunun ötesinde işlem temelinin çökmesinden de söz edilemeyeceğini hükme bağlamıştır.

Aynı yönde Frankfurt Eyalet Mahkemesi’nce verilen bir kararda, ${ }^{35}$ salgına karşı alınan kamusal önlemler kapsamında perakende satış yapan mağazaların kapatılmasının kira hukukuna ilişkin hükümler kapsamında ayıp teşkil etmeyeceği ve bu nedenle de kira bedelinde indirim hakkının gündeme gelemeyeceğine hükmedilmiştir. Bu kapsamda ayrıca Mahkeme, şirketin devamlılı̆̆ına yönelik istisnai bir tehdit olmadığ 1 sürece, işlem temelinin çökmesinden de bahsedilemeyeceğini ve bu nedenle, sözleşmenin değişen koşullara uyarlamasının da talep edilemeyeceğini belirtmiştir. Söz konusu davada ünlü bir giyim firmasının şubesini işleten davalı kiracı, salgın önlemleri neticesinde mağazasının 18 Mart - 20 Nisan 2020 tarihleri arasında kapalı kaldığını, satışlarda büyük çapta

32 LG Heidelberg, Urteil vom 30.07.2020 - 5 O 66/20.

33 LG Zweibrücken, Urteil vom 11.09.2020 - HK O 17/20.

34 LG Wiesbaden, Urteil vom 05.11.2020 - 9 O 852/20.

35 LG Frankfurt, Urteil vom 05.10.2020, Az. 2-15 O 23/20. 
(geçen yılın mart ayına göre \%54 oranında) düşüş yaşandığını, söz konusu gelir kaybı dolayısıyla da nisan ayı kirasının ödenmesinde güçlük yaşandığını, bu durumun da ayıp olarak kabul edilmesi icap ettiğini ileri sürerek kira bedelinde indirim yapılması gerektiğini, her koşulda pandemi krizi dolayısıyla işlem temelinin çöktüğünü ve sözleşmenin uyarlanması gerektiğini savunmuştur.

Eyalet Mahkemesi, davalı kiracının savunmasını yerinde görmeyerek, kamu hukukundan doğan kısıtlama ve yasakların bilhassa ticari amaçla yapılan kira sözleşmeleri bakımından ayıp teşkil edebileceği kabul edilse de, somut olayda ayıptan söz edilemeyeceği kanaatine varmıştır. Mahkemeye göre ayıptan söz edilebilmesi için kamusal yasaklama nedeninin kiralanan mülkün kendisinden kaynaklanması gerekmektedir ki salgın hastalık nedeniyle kapanmaların öngörülmesinde bu durumdan söz edilemez. Mağazaların kapatılmasının ancak mağazadaki insan trafiğinin salgını tetikleyici olmasıyla ilgisi olabilir, bununla birlikte bu durumun kiralananın niteliğiyle doğrudan bir bağlantısı bulunmamaktadır.

Mahkemeye göre, işlem temelinin çökmesinden de söz edilemez. Bir kiracının, öngörülemeyen olayların ortaya çıkması durumunda, üzerinde anlaşmaya varılan kira ödemesinde indirim talep edebileceği kabul edilebilir. Ancak somut olayda mahkemeye göre, sözleşmenin değişen koşullara uyarlanması imkânı ancak "hukuk ve adaletle bağdaşmayan tahammül edilemez bir sonucun ortaya çıkmaması için kaçınılmaz görünüyorsa” gündeme gelebilecektir. Böylesine istisnai bir durum ise ancak ve ancak taraflardan birinin iktisadi varlığına yönelik bir tehdidin varlığı halinde kabul edilebilir. Somut olayda ise mahkemeye göre, davalı giyim firması bakımından böylesi bir ekonomik tehdit söz konusu değildir.

Bir diğer ifadeyle; geçici mali darboğaz, ekonomik varoluş ve devamlılığa ilişkin bir tehdit teşkil etmez. Ayrıca somut olay bakımından davalı giyim firması, kısa süreli çalışmaya geçmiş ve bu sayede tasarruf sağlamıştır ve federal hükümetin pandemiye ilişkin olarak yasada öngördüğü kısa vadeli değişiklikler, Covid19 salgını ile ilgili ödeme zorlukları nedeniyle işten çıkarılmaları engellemiştir.

Öte yandan Münih I Eyalet Mahkemesi, 22.09.2020 tarihli kararında ${ }^{36}$ Covid-19 pandemisi dolayısıyla alınan önlemler kapsamında temel ihtiyaçların satıldığı iş yerleri dışında tüm mağazaların kapatılması ya da bunların kullanım alanlarının daraltılması veya müşteri sayısı sınırlaması getirilmesinin ayıp teşkil ettiğini ve bu nedenle kira bedelinde indirim hakkının kullanılabileceğini karara bağlamıştır.

Somut olayda davacı, davalı kiracıya mağaza olarak kullanılmak üzere yaklaşık $3.000 \mathrm{~m}^{2}$ lik bir işyerini kiralamıştır. Davalı kiracı, söz konusu işyerinde bir mobilya mağazası işletmektedir. Covid-19 salgını sebebiyle davalı kiracı, 2020 İlkbaharında alınan önlemler kapsamında mağazasını tamamen kapatmak zorunda kalmış ve sonrasında önlemlerin gevşetilmesi ile de işyerinin yalnızca $800 \mathrm{~m}^{2}$ 'lik alanını (her $20 \mathrm{~m}^{2}$ 'ye bir müşteri düşecek şekilde) kullanmasına izin verilmiştir. Bunlardan dolayı kiracı, kiralananın pandemi dolayısıyla ayıplı hale geldiğini ileri sürerek Nisan 2020'den itibaren kira bedelini \%100 olacak şekilde indirmiş; bir diğer ifadeyle kira bedelini ödememeye başlamıştır. Bununla birlikte davacı kiraya veren ise kiracının tüm kira bedelinden sorumlu olduğunu ileri 
sürerek (kiracı tarafından ödenmeyen) Nisan - Haziran 2020 dönemi için yaklaşık 224.000,00 EUR kira bedelinin tahsili için dava açmıştır.

Kısmen kabul edilen davada Münih Eyalet Mahkemesi, kiracının kısmen ve kademeli şekilde kira bedelinde indirim yoluna gidebileceğine, çünkü kiralananın kullanımını etkileyen mevcut önlem ve kısıtlamaların kiralananı ayıplı hale getirdiğine işaret etmiştir. Kararın gerekçesini Alman Federal Mahkemesi’nin aşağıda değinilen pek çok kararına dayandıran Eyalet Mahkemesi, bilhassa savaş dönemlerinde öngörülen resmi yasakların pek çok işyeri bakımından kiralanan işyerinin sözleşmeye uygun şekilde kullanılmasını imkânsız hale getirdiğine ve bu durumun da ayıp teşkil ettiğine değinmiştir. Öte yandan, kiralanan işyerini ayıplı hale getiren unsurlar üzerinde duran Eyalet Mahkemesi, kamu hukukundan doğan sınırlamaların kiralananın özellik, kullanılabilirlik ve durumunu etkilemesi halinde ayıp teşkil edeceğine vurgu yaparak söz konusu kısıtlamaların somut olarak kiralananın kullanımını etkilemesi gerektiğini belirtmiştir.

Somut olayda taraflar, kiralanan işyerinin mobilya mağazası olarak faaliyet göstereceği hususunda anlaşmış olup söz konusu kullanım amacı, kamu hukukundan doğan pandemi kısıtlamaları nedeniyle etkilenmiş ve hatta kimi zamanlarda tamamen ortadan kalkmıştır. Kaldı ki söz konusu sınırlamalar, kiracının risk alanına dâhil olan (bir diğer ifadeyle kiracıya yüklenebilecek) sebeplerden kaynaklanmamıştır.

Sözleşmede yer alan ve kiracının işletmenin faaliyetlerinin yürütülmesi bakımından gerekli tüm (kamusal) izinleri - tüm sorumluluk kendisine ait olmak üzere - alacağı ve yenileyeceğini öngören sözleşme maddesinin somut olay bakımından bir değişikliğe yol açmayacağı çünkü söz konusu hüküm ile inşaat ya da iş hukukundan doğan izinlerin kastedildiği belirtilmiştir.

Eyalet Mahkemesi’ne göre, mobilya mağazasının kullanılmasının kapsamlı şekilde sınırlandırıldığ 1 dönem için kira bedeli \%80 oranında indirilebilir. Mağaza alanının yalnızca \%25’inin kullanıldığı ve müşteri trafiğinin oldukça az olduğu Mayıs 2020 bakımından ise \%50 indirim yapılması uygun olmakla, mağaza alanının tamamının kullanıldığı ancak sadece müşteri sayısında sınırlama öngörülen Haziran 2020 için ise \%15 indirimin gündeme gelebileceği kabul edilmiştir.

Yukarıda özetlenen Münih Eyalet Mahkemesi kararında işaret edilen Alman Federal Mahkemesỉnin (Reichsgericht) 1. Dünya Savaşı zamanında yüzyılı aşkın bir süre önce verdiği bazı kararlarında savaş döneminde getirilen dans etme yasağının bu amaçla (dans faaliyetleri) kiralanmış iş yerleri bakımından bir ayıp teşkil ettiğini ve kira bedelinde indirim hakkının kullanılabileceğini hükme bağlamıştır ki benzer bir yaklaşım Covid-19 pandemisi döneminde de salgınla mücadele için alınan önlemler kapsamında kapatılan işyerleri bakımından da benimsenebilir.

1. Dünya Savaşı döneminde Almanyada bilhassa geceleri çalışan balo ve dans salonları ile gece kulüpleri kapatılmış ya da yalnızca sınırlı şekilde faaliyet gösterebilmiştir. Bunun yanında ayrıca marketler, değirmenler ve birahaneler de kapatılmış ve kira sözleşmesinden doğan çeşitli sorunlar ortaya çıkmıştır. 
Alman Federal Mahkemesi 09.11.1915 tarihli "Tanzlokal” (dans lokali) kararında, ${ }^{37}$ ağırlıklı olarak dans kulübü olarak faaliyet gösteren bir işletme sahibi açısından savaş döneminde öngörülen dans etme yasağı dolayısıyla kira bedelinde indirim hakkının gündeme gelebileceğini belirtmiştir. Anılan kararda öncelikle taraflar arasında kira sözleşmesi olarak adlandırılan sözleşmenin bir leasing anlaşması olduğu tespit edilmiştir. Alman Medeni Kanunu hükümleri uyarınca ( $\$ 581 \mathrm{f}$. 1 BGB) leasing sözleşmelerine de - bünyesine uygun düştüğü ölçüde - kira sözleşmesi hükümleri uygulandığından, kira sözleşmesine ilişkin düzenlemeler uyarınca kira bedelinde indirim hakkının uygulanabilmesi için sözleşmede öngörülen kullanım amacının etkilenmiş olması gerekmektedir.

Federal Mahkeme, dans işletmeciliğinin sözleşmenin özünü oluşturduğundan bahisle, dans etmenin yasaklanması ile leasing konusu lokalin kullanılamaz hale geldiğini çünkü somut olayda işletme konusu mekânda ağılıklı olarak dans faaliyeti yapıldığını ve bu durumun yalnızca sözleşmenin akdedilmesinden savaş dönemine kadar geçen süre için geçerli olmadığını, aynı zamanda sözleşmenin kurulmasından önceki 30 yıllık süreçte de söz konusu mekânın adeta bir dans kulübü olarak işletildiğini belirtmiştir. Mahkemeye göre; sözleşmenin kullanım amacının ortadan kalktığına işaret eden bir başka gösterge ise dans faaliyetinin işletmenin esas gelir kaynağıdır ve işletmedeki yiyecek ve içecek siparişleri yalnızca ya da çoğunlukla dans etmeye gelen müşteriler tarafından verilmektedir.

Federal Mahkeme; risk dağılımına vurgu yaparak, halka açık yerlerde dans etme yasağı getirilmesinin - kiralayandan kaynaklanmayan bir sebeple - yasak boyunca kira konusundan yararlanmayı imkânsız hale getirdiğine işaret etmiştir. Söz konusu yasak, uzun ylllardır dans faaliyeti için kullanılan leasing konusu mülkün kendisine yönelik olup yasakla birlikte söz konusu faaliyet gereği gibi icra edilemediğinden, kiralananın sözleşmede öngörülen kullanım amacına uygun şekilde kullanılması imkânsiz hale gelmiş olup bu durumda Medeni Kanun’un $₫ 537$ ( $\$ 581$ f. 2 atfiyla) hükmünün uygulanabileceği karara bağlanmıştır. Mahkemeye göre; işletmenin dans faaliyetleri için kullanıldığı bilgisinin sözleşmede yer almaması, değerlendirme açısından önem arz etmemektedir çünkü somut olaydan anlaşıldığı üzere; sözleşme tarafları, kiracının söz konusu işletmeyi yalnızca dans faaliyetleri yürütmek amacıyla kiraladığını bilmektedir.

Federal Mahkeme’nin 20.02.1917 tarihli bir başka kararında; ${ }^{38}$ yine benzer şekilde, dans yasağ nedeniyle ortaya çıkan durumun BGB’nin $\$ 537$ hükmü uyarınca ayıp teşkil ettiği belirlenmiştir. Ancak söz konusu karara konu olan somut olayda; yukarda anılan karardaki durumdan farklı olarak, sözleşmenin kendisinden açıkça leasing konusu yerin dans faaliyetleri için kiralanmış olduğu anlaşılmaktadır. Buna göre; kamuya açık yerlerde dans etmenin yasaklanması, sözleşme konusu yerin sözleşmede öngörülen kullanım amacına uygun şekilde işletilmesine engel olmaktadır. ${ }^{39}$

37 RGZ 87, 277 - III 145/15.

38 RGZ 89, 203 - III 384/16.

39 Konu ile ilgili olarak nazara alınabilecek restoranlarda uygulanan sigara içme yasağının ayıp teşkil edip etmediğinin ve kira bedeli üzerindeki etkisinin değerlendirildiği Alman Federal Mahkemesi’nin 13.07.2011 tarihli kararında Mahkeme, söz konusu yasak ile işletmenin faaliyetinin imkânsız hale gelmediğini, bir diğer ifadeyle yasağın işletmenin faaliyeti üzerinde herhangi bir etkisi olmadığını hükme bağlamıştır. BGH, 13.07.2011 - XII ZR 189/09, NJW 2011, s. 3151 vd. Kararla ilgili detaylı inceleme ve görüşler için bkz. Jürgen Hübner, Das Gesetz zur Abmilderung der Folgen der Covid19-Pandemie im Geschäftsraummietrecht - nicht mehr als ein erster Schritt, ZfIR 2020, s. 277 vd.; Sittner s. 1171 vd. 
Yukarıda değinilen yasal karinenin yürürlüğe girmesinden sonra verilen ilk yargı kararlarından biri olan Münster Eyalet Mahkemesi’nin 19.02.2021 tarihli kararında, ${ }^{40}$ koronavirüs ile ilgili öngörülen kamusal kısıtlamaların, kira bedelinde indirim hakkına sebebiyet vermeyeceği, bir diğer ifadeyle ayıp teşkil etmeyeceği, öte yandan BGB’nin 275. maddesi uyarınca da imkânsızlıktan söz edilemeyeceği hükme bağlanmıştır. Mahkemeye göre, BGB’nin 313. maddesinin ve Alman Medeni Kanunu’nu Düzenleyici Kanun'un 240. maddesinin 7. bendinde öngörülen yasal karinenin ${ }^{41}$ ilk bakışta somut olay bakımından nazara alınabileceği kabul edilse de, söz konusu karine 313. maddede öngörülen sözleşmenin değişen koşullara uyarlanması bakımından yalnızca (sözleşme şartlarının değişmesine yönelik) ilk kritere ilişkindir ki uyarlamanın diğer şartlarına ilişkin olarak herhangi bir karine söz konusu değildir. Bu bağlamda somut olay kapsamında değerlendirme yapan mahkeme, altı hafta süreyle tamamen kapanma ve sonraki dokuz iş günü için geçerli olan işletme kısıtlamalarının ve ayrıca \% 10 oranındaki satış kaybının, herhangi bir sözleşme uyarlamasını haklı çıkarmayacağını karara bağlamıştır.

Münih Yüksek Bölge Mahkemesi’nin 17.02.2021 tarihli kararında ${ }^{42}$ da pandemideki ilk dalga ve buna bağlı olarak 18.03.2020 - 27.04.2020 tarihleri arasında öngörülen önlemlerin işyeri kira sözleşmeleri bakımından kira bedeline ilişkin bir etkisi olup olmadığı ve kira bedelinin indirimine yol açıp açmayacağı değerlendirilmiştir. Mahkemeye göre; işletme faaliyetine getirilen sınırlamalar bakımından ayıptan söz edilmesi mümkün değildir çünkü BGB’nin ilgili hükümlerine göre ayıbın varlığından bahsedilebilmesi için kiralananın kullanımın kısıtlanması ile kiralık yerin özel niteliği, durumu veya konumu arasında doğrudan bir bağlantı mevcut olmalıdır ki pandemiyle mücadele kapsamında alınan önlemler bakımından böylesi bir bağlantının kurulması mümkün değildir. Bir diğer ifadeyle; kiraya verenin kiralananı teslim ve kira süresi boyunca sözleşmede öngörülen kullanım amacına uygun şekilde bulundurma borcu, kiralananın akla gelebilecek her durum ve koşulda kiralananın (içinde bulunduğu) mevcut durumunu garanti ettiği ve edeceği şeklinde yorumlanamaz.

Mahkemeye göre, pandemi önlemleri dolayısıyla işletme faaliyetlerinin kısıtlanması sebebiyle kira sözleşmesinin uyarlanması ve kira bedelinde indirim yapılması BGB’nin 313. maddesi uyarınca temelde mümkündür. Bir diğer ifadeyle; pandeminin neden olduğu faaliyet yasağının, 313. madde anlamında kira sözleşmesinin temeli haline gelen koşulları ciddi şekilde değiştirdiği ifade edilebilir. Bununla birlikte Senato; ancak sözleşme koşullarındaki önemli nitelikteki değişimlerin sözleşmeye müdahaleyi haklı çıarabileceğini belirterek, her sözleşme ve her somut durum için, sözleşme koşullarında önemli bir değişikliğin olup olmadığının araştırılması gerektiğine işaret etmiştir. $\mathrm{Bu}$ bağlamda; kiracının kiralanan yeri somut kullanım amacına bakılmaksızın bu türden işletmelerin faaliyetini yasaklayan genel bir işletme yasağı getirilmesi durumunda sözleşme koşullarında önemli ölçüde bir değişiklikten söz edilebilir. Öte yandan, Mahkemece belirtildiği üzere, sözleşmenin değişen koşullara uyarlanması bakımından aranan tek şart bu durum değildir.

40 LG Münster, Urteil vom 19.02.2021 - 23 O 18/20.

41 Mahkemeye göre, söz konusu yasal karine geriye dönük olarak 2020'nin ilkbahar aylarında geçerli olan kapanma ve kısıtlamalar bakımından da uygulama alanı bulabilecektir. 
Karlsruhe Yüksek Bölge Mahkemesi'nin 24.02.2021 tarihli kararında ${ }^{43}$ ise Covid-19 salgını ile mücadele kapsamında alınan önlemler sırasında (18 Mart - 19 Nisan 2020 tarihleri arasında) işyerini kapatmak zorunda kalan bir işletme sahibinin kira ödemelerini askıya alamayacağı ya da kira bedelinde indirim talep edemeyeceği hükme bağlanmıştır. Mahkemeye göre salgına karşı öngörülen kamusal yasakların kiralanan işyerini ayıplı hale getirmesi söz konusu değildir. Kiralanan işyerinin mevcut durumu, bir perakende mağazasının sözleşmede öngörülen kullanım amacının gerçekleşmesine (satış ve depolama alanı olarak kullanılmasına) hala imkân tanıdığından, kira ödeme yükümlülügü bu açıdan da ortadan kalkmamıştır. Bununla beraber Yüksek Mahkeme, işlem temelinin çökmesi ilkesi ekseninde sözleşmede belirlenen kira bedelinin tamamının ödenmesinin kiracı bakımından bir orantısızlık yaratıp yaratmayacağının kural olarak değerlendirilebileceğini ifade etmiştir. Sözleşmenin uyarlanmasının ancak istisnai bir durum olarak gündeme gelebileceğini belirten Yüksek Mahkeme, uyarlama talebinin ancak sözleşmeye mevcut haliyle devam etmesinin kiracıya ekonomik açıdan büyük zarar vereceğinin ya da kiracının ekonomik mahvına sebep olacağının kiracı tarafından ispat edilmesi halinde kabul görebileceğini belirtmiştir. Mahkemeye göre, somut olay özelinde değerlendirme yapılması gerekmekte olup anılan şartın gerçekleşip gerçekleşmediğinin tespiti bakımından satışlardaki düşüş oranı, e-ticaret veya kamu hizmetleri yoluyla sağlanan gelir düzeyi, örneğin kısa süreli çalışma yoluyla tasarruf edilen harcamalar gibi faktörler bu incelemede nazara alınmalıdır.

\section{TÜRK HUKUKU AÇISINDAN DEĞERLENDIRME}

\section{A. GENEL OLARAK}

Yukarıda Almanya bakımından kapsamlı şekilde ele alındı̆̆ı üzere; Türkiye'de de Covid-19 pandemisi ile mücadele kapsamında çeşitli alanlarda günlük hayatı ve bu bağlamda günlük hukuki ilişkileri önemli ölçüde etkileyen kararlar ve kamusal önlemler alınmıştır. Bunlar arasında en dikkat çekenlerden biri olan İçişleri Bakanlığı’nın 16.03.2020 tarihli genelgesi ile "81 ilde, tiyatro, sinema, gösteri merkezi, konser salonu, nişan/düğün salonu, çalgılı/müzikli lokanta/kafe, gazino, birahane, taverna, kahvehane, kıraathane, kafeterya, kır bahçesi, nargile salonu, nargile kafe, internet salonu, internet kafe, her türlü oyun salonları, her türlü kapalı çocuk oyun alanları (AVM ve lokanta içindekiler dahil), çay bahçesi, dernek lokalleri, lunapark, yüzme havuzu, hamam, sauna, kaplıca, masaj salonu, SPA ve spor merkezlerinin faaliyetlerinin geçici bir süreliğine durdurulacağı" duyurulmuştur.

Bu çalışmada ele alınan konu özelinde belirtmek gerekir ki 26.03.2020 tarih ve 31080 (Mükerrer) sayılı Resmî Gazetede yayımlanan 7226 Bazı Kanunlarda Değişiklik Yapılmasına Dair Kanun ${ }^{44}$ ile 7226 sayılı Kanun'un Geçici 2. maddesi ile 01.03.2020 tarihinden 30.06.2020 tarihine kadar geçecek dönemde işyeri kira bedel ve bedellerinin ödenememesinin kira sözleşmesinin feshi ve tahliye sebebi oluşturmayacağı açıkça hüküm altına alınmıştır. Buna göre anılan zaman aralığında (01.03.2020

43 OLG Karlsruhe, Urteil vom 24.02.2021 - 7 U 109/20.

44 Resmî Gazete, 26.03.2020, sayı: 31080 (mükerrer). 
tarihinden 30.06.2020 tarihine kadar) işleyecek işyeri kira bedelinin ödenememesi durumunda kiraya verence fesih ya da tahliye yolunda gidilemeyecektir.

Türk Hukuku açısından da pandemiyle mücadele önlemleri kapsamında işletmelerin kapatılması durumunda kira bedelinin ödenmesine ilişkin edimin hukuki açıdan akıbeti hususunda uyarlama ve kiralananın ayıplı hale gelmesi ile borcun ifasının imkansızlaşması iddiaları gündeme gelebilir.

\section{B. COVID-19 PANDEMISININ MÜCBIR SEBEP NITELIĞi}

Pandemi önlemleri kapsamında nazara alınması gereken ilk husus, bir bulaşıcı hastalık olan koronavirüs ve buna bağlı öngörülen önlemlerin bir mücbir sebep teşkil edip etmediğidir.

Yargitay Hukuk Genel Kurulu’nun 2017/90 E. - 2018/1259 K. sayll kararında: "Bu noktada "mücbir sebep" kavramı üzerinde kısaca durulmasında fayda vardır. Mücbir sebep, sorumlu veya borçlunun faaliyet ve işletmesi dışında meydana gelen, genel bir davranış normunun veya borcun ihlâline mutlak ve kaçınılmaz bir şekilde yol açan, öngörülmesi ve karşı konulması mümkün olmayan olağanüstü bir olaydır (Eren, Fikret: Borçlar Hukuku Genel Hükümler, Ankara 2017, s. 582). Deprem, sel, yangın, salgın hastalık gibi doğal afetler mücbir sebep sayılır. Yukarıdaki açıklamadan da anlaşılacağı gibi mücbir sebebin birtakım unsurları vardır. Öncelikle mücbir sebep, zorlayıcı bir olaydır. Bu olay doğal, sosyal veya hukuki bir olay olabileceği gibi insana bağlı beşeri bir olay da olabilir. Bu olay, zarar verenin faaliyet ve işletmesi dışında kalan bir olay olmalıdır. Mücbir sebep nedeniyle zarar veren, bir davranış normunu veya sözleşmeden doğan bir borcu ihlal etmiş olmalıdır. Yine mücbir sebep, davranış normunun ihlali ya da borca aykırılığın sebebi olmalı ve kaçınılmaz bir şekilde buna yol açmış olmalıdır. Kaçınılmazlık kavramı, mücbir sebep yönünden karşı konulmazlık ve önlenemezlik kavramını da kapsar. Mücbir sebebin bir diğer unsuru ise öngörülmezliktir...” ifadeleri ile mücbir sebep kavramının tanımı ve kapsamına yer verilmiştir. Öğretide ise mücbir sebep; borçlunun faaliyet ve işletmesi dışında meydana gelen, genel bir davranış normunun ya da borcun ihlaline, kaçınılmaz ve mutlak şekilde neden olan, öngörülmesi ve karşı konulması mümkün olmayan olağanüstü bir olay biçiminde tanımlanmaktadır. ${ }^{45}$

Türk hukukunda küresel çaptaki bir bulaşıcı hastalığın yarattığı can güvenliği tehlikesi ve salgınla mücadele kapsamında alınan kamusal önlemlerin mücbir sebep olarak kabul edilip edilmediği hususunda tam bir açıklık bulunmamakla birlikte, ${ }^{46}$ Yargitay 3. Hukuk Dairesi’nin 17.11.2020 tarih ve E. 2020/2910 - K. 2020/6680 sayılı güncel kararında: "Uzun süreli kira sözleşmelerinde edimler arasındaki dengenin aşırı bozulması ve sözleşmenin taraflar açısından çekilmez hale gelmesi halinde kira parasının günün ekonomik koşullarına uyarlanması için her zaman uyarlama davası açılabilir. O halde Mahkemece yapılacak iş; az yukarıda açıklanan uyarlama davalarında uygulanması gereken ilke ve esaslar, belirtildiği şekilde tek tek ortaya konulmalı ve konularında uzman üç kişilik bilirkişi kurulundan, tüm bu veriler, kiralananın niteliği, kullanma alanı, konumu, bölgedeki kira parasını da etkileyecek normalin üstündeki imar ve ticaret değişiklikleri, emsal kira paraları, vergi ve amortisman

45 Eren, s. 582; Kemal Oğuzman/ Turgut Öz, Borçlar Hukuku Genel Hükümler Cilt I, 18. Baskı 2020, s. 418.

46 Arzu Oğuz, "COVID19, Mücbir Sebep ve sözleșmelere Etkisi”, Terazi Hukuk Dergisi, 2020, Cilt:15, Sayı:166, s. 1276. 
giderlerindeki artışlar, döviz kurlarındaki ani ve aşırı iniş ve çıkışlar ile ülkeyi sarsan ciddi ekonomik kriz veya deprem, sel, yangın, salgın hastalık gibi mücbir sebep sayılan doğal afetlere bağlı ödeme esaslarının yeniden düzenlenmesini gerektirecek olayların varlığı araştırılıp değerlendirilmek suretiyle bir rapor alınmalı ve hasıl olacak sonucuna göre karar verilmesi gerekirken yanılgılı değerlendirme ile kira bedelinin tespitine yönelik karar verilmesi usul ve yasaya aykırı olup bozmayı gerektirmiştir." ifadelerine yer verilerek salgın hastalık mücbir sebep kapsamında değerlendirilmiştir. Böylece uygulama bakımından yol gösterici olabilecek bir karar ortaya çıkmıştır. Benzer şekilde pandemi döneminde kaleme alınan eserlerde, salgın hastalığın insandan insana bulaşması ve küresel çapta yayılması ile salgınla mücadele kapsamında alınan kamusal önlemlerin ticaret hayatına büyük darbe vurduğu nazara alınarak mücbir sebep olarak değerlendirilmesi gerektiği ileri sürülmüştür. ${ }^{47}$ Mevcut koronavirüs salgınına karşı konulması mümkün olmadığı gibi salgının doğurduğu sonuçlar da öngörülebilir nitelikte değildir. ${ }^{48}$ Öte yandan taraflar arasındaki sözleşmede de mücbir sebep durumuna ilişkin olarak bir düzenleme öngörülmüş olması mümkündür. Akdedilen sözleşmede mücbir sebep halleri örnekseyici olarak sayılmış olabilir. Örneğin taraflar arasındaki sözleşmede doğrudan "salgın hastalık", "bulaşıcı hastalık", "epidemi/ pandemi” hallerinin mücbir sebep sayılacağı düzenlenmiş olabileceği gibi pandemiyle mücadele kapsamında getirilen kısıtlamaları kapsayacak şekilde "yetkili mercilerin kararları", "idarenin tasarrufları", "seyahat yasağı”, "sokağa çıkma yasağı”, "ithalat ve ihracat yasakları" ya da "karantina" gibi ifadeler de sözleşmede mücbir sebep olarak yer alabilir. ${ }^{49}$

\section{IMKÂNSIZLIK}

TBK’nın 136. maddesi uyarınca: "Edimin yerine getirilmesi borçlunun sorumlu tutulamayacağı bir sebeple imkânsız hale gelmiş ise borç sona erer.” TBK’nın 27. maddesinin ilk fıkrası uyarınca da başlangıçtaki imkânsızlığın varlığı hâlinde sözleşme kesin hükümsüzdür. ${ }^{50}$

İki tarafa borç yükleyen sözleşmelerde edimin ifası, borç ilişkisinin kurulmasından sonra borçlunun kusuru olmaksızın imkânsız hale gelmişse bu durumda, TBK 136. maddesi gereğince

47 Oğuz, s. 1276; Abdülkerim Yıldırım, “Koronavirüs Krizinin Özel Hukuk Sözleşmelerine Etkisi”, Terazi Hukuk Dergisi, 2020, Cilt:15, Sayı:165, s. 987; Ş. Barış Özçelik, “Covid-19 Salgını Çerçevesinde Alınan Önlemlerin Sözleşme Hukuku ve Mücbir Sebep Kavramı Açısından Değerlendirilmesi,” Covid-19 Salgınının Hukuki Boyutu (ed. Muhammet Özekes), İstanbul 2020, On İki Levha Yayıncılık, ss. 283 - 293, s. 288; Özge Yücel, “Covid-19 Salgınının Borç İlişkilerine Hukuksal Etkileri”, Terazi Hukuk Dergisi, Cilt: 15, Sayı: 166, 2020, s. 1199; Ferhat Kayış, "KOVİD-19 (Koronavirüsü) Nedeniyle İşyeri Kira Sözleşmelerinin Yeni Koşullara Uyarlanması”, Yaşar Hukuk Dergisi, Cilt: 2, Sayı: 2 Özel Sayı, 2020, s. 3; Yaşar Can Göksoy, "Basiretli İş Adamı Gibi Hareket Etme Yükümlülüğü (TTK m. 18) Bağlamında Covid-19 Pandemisinin Tacirlerin Sözleşmeden Doğan Yükümlülükleri Üzerindeki Etkileri”, Yaşar Hukuk Dergisi, Cilt: 2, Sayı: 2 Özel Sayı, 2020 , s. 3. Covid-19 salgınının önlenemez ve öngörülemez etkileri nazara alındığında ortaya çıkan mücbir sebep halinin genel anlamda basiretli iş adamı gibi hareket etme yükümlülüğü öne sürülerek bertaraf edilemeyeceği yönünde ayrıntılı açıklamalar için bkz. Göksoy, s. 4 vd. Aynı yönde ayrıca bkz. Sinan Sarıkaya, "Basiretli Tacir İlkesi Işı̆̆ında Koronavirüs (Covid-19) Salgınının Sözleşmelerdeki Ceza Koşuluna Etkisi”, Covid-19 Salgınının Hukuki Boyutu (ed. Muhammet Özekes), İstanbul 2020, On İki Levha Yayınc1lık, ss. 629-645, s. 642.

48 Yildirım, s. 987.

49 Göksoy, s. 4; Özçelik, s. 291.

50 Fikret Eren, Borçlar Hukuku Genel Hükümler, Ankara 2020, 25. Baskı, s. 1329. 
borç kendiliğinden sona erecektir. ${ }^{51}$ Bir mücbir sebep neticesinde edimin ifası imkânsız hale gelmişse, borçlunun sorumlu olmadığı sonraki imkansızlıktan söz edilebilir ki böylece mücbir sebep neticesinde ediminin ifası imkânsız hale gelen borçlu, herhangi bir tazminat ödemeksizin borcundan kurtulur. ${ }^{52}$

Bununla birlikte imkansızlığın borcu sona erdirebilmesi için kalıcı ve kesin olması gerekir ki geçici imkânsızlık borcu sona erdirmemektedir. ${ }^{53}$ Geçici ifa imkansızlığı bakımından TBK'da bir düzenleme bulunmamaktadır. Öğreti ve yargı kararlarında da geçici imkansızlığın hukuki niteliği ve doğuracağı sonuçlar bakımından çeşitli görüşler ileri sürmektedir. ${ }^{54}$ Öğretide bazı yazarlar; geçici ifa imkansızlığı durumunda, borçlu temerrüdüne ilişkin düzenlemelerin uygulama alanı bulacağını savunmaktadır. ${ }^{55}$ Yargitay Hukuk Genel Kurulu’nun 28.04.2010 tarih ve 2010/15-193-235 sayılı kararı: "İfa imkânsızlığı borcu sona erdiren nedenlerdendir. Gerçekten BK. md. 117/1'e göre " borçluya isnat olunamayan haller münasebetiyle borcun ifası mümkün olmazsa borç sakıt olur". İfa imkânsızlığı ortaya çıkış nedenlerine göre bazı ayırımlara tabi tutulmaktadır. Bu ayırımlardan birisi de objektif imkânsızlık (daimi imkânsızlık)-geçici imkânsızlık ayırımıdır. Şayet ifa imkânsızlığı sadece sözleşmenin tarafları bakımından değil, herkes için söz konusu ise buna objektif imkânsızlık denilmektedir. Objektif imkânsızlıkta sözleşme esasen BK. md.20 uyarınca butlanla batıldır (geçersizdir) ve ayrıca feshi gerekmez. Hâlbuki geçici imkânsızlıkta akdin ifası (icrasının istenmesi) bir hadisenin gerçekleşmesine bağlıdır. Ancak o hadise tahakkuk ederse akdin icrası istenebilir. (...) Şüphesiz geçici imkânsızlığın varlığı, beraberinde tarafların bu sözleşmeyle ne kadar süre bağlı kalacakları sorununu getirir. Bu konudaki kural "ahde vefa=söze sadakat" ilkesi gereği tarafların sözleşmeyle bağlı tutulmasıdır. Ancak bazı özel durumlar vardır ki, tarafları o sözleşmeyle bağlı saymak hem onların ekonomik özgürlüklerini engeller hem de bir başkası ile sözleşme yapma fırsatını ortadan kaldırır. Uygulamada, geçici imkânsızlık halinde tarafların o sözleşmeyle bağlı tutulma süresine "akde tahammül süresi" denilmektedir. Bu sürenin gerçekleşip gerçekleşmediğini de her somut olaya göre ve onun çerçevesinde değerlendirmek gerekir” hükmünü haizdir. Buna göre; geçici imkânsızlık durumunda, tarafların bir süre daha sözleşme ile bağlı kalması kabul edilerek “akde tahammül süresi”nin beklenmesi, ancak bu süre sonlanmış sayılırsa sözleşmenin artık bağlayıcı

51 Ahmet Kılıçoğlu, Bulaşıcı Hastalığın Borç İlişkilerine Etkisi, Yayımlanmamış Makale https://www.turkhukukkurumu. org.tr/duyurular/377-bulasici-hastaligin-borc-iliskilerine-etkisi.html. (Son Erişim Tarihi: 29.03.2021)

52 Oğuz, s. 1277; Eren, s. 1333.

53 Ahmet Kılıçoğlu, Yayımlanmamış Makale; Yıldırım, s. 989.

54 Görüşler ve tartışmalar bakımından ayrıntılı bilgi için bkz. Başak Baysal, Sözleşmenin Uyarlanması, TBK m. 138, Așırı Iffa Güçlüğü, 3. Baskı, İstanbul 2019, N. 622 vd.; Fatih Gündoğdu, Borca Aykırllık Hallerinden Kusurlu İfa İmkansızlı̆ğ ve Hukuki Sonuçları, İstanbul 2014, s. 106 vd.

55 Eren, s. 1454; Özçelik, s. 288. Konuya ilişkin değerlendirmeler için bkz. ve karş. Melek Bilgin Yüce, "Koronavirüs Salgını Nedeniyle Hükümet Kararıyla Kapatılan İşyerlerinin Kira Sözleşmelerinin Akıbetinin Değerlendirilmesi”, Yayımlanmamış Makale, Lexpera, https://blog.lexpera.com.tr/koronavirus-salgini-nedeniyle-hukumet-karariylakapatilan-isyerlerinin-kira-sozlesmelerinin-akibetinin-degerlendirilmesi/ (Son Erişim Tarihi: 11.05.2021); Başak Baysal/ Murat Uyanık/ M. Selim Yavuz, "Koronavirüs 2019 (COVID-19) ve Sözleşmeler”, Yayımlanmamış Makale, Lexpera, https://blog.lexpera.com.tr/koronavirus-2019-ve-sozlesmeler/ (Son Erişim Tarihi: 11.05.2021); Fatih Gündoğdu/ Nihal Ural, "Koronavirüs (COVID-19) Tedbirlerinin Kira Sözleşmelerine Etkisi", Yayımlanmamış Makale, Lexpera, https:// blog.lexpera.com.tr/koronavirus-tedbirlerinin-kira-sozlesmelerine-etkisi/ (Son Erişim Tarihi: 11.05.2021). 
olmayacağ 1 şeklinde bir görüş oluşturulmuştur. İfade edildiği üzere, akde tahammül süresinin ne kadar olacağı her somut olayın koşullarına göre o olaya özel olarak tespit edilebilecektir.

Öğretide bir başka görüş ise mücbir sebep ortadan kalkana kadar bu süre boyunca karşılıklı olarak borçların askıya alınmasının menfaatler dengesinin korunması bakımından daha uygun olacağını ileri sürmektedir. ${ }^{56}$ Buna göre; salgın döneminde geçici imkansızlık durumu (salgın koşulları) ortadan kalkıncaya kadar tam iki tarafa borç yükleyen sözleşmelerde karşılıklı borçlar askıya alınarak tarafların borcun ifasını talep hakkı ertelenmelidir. ${ }^{57}$ Bununla birlikte; bu görüşe göre, geçici imkansızlığın ne kadar süreceği bilinemiyor ya da öngörülemiyorsa veyahut imkansızlık ortadan kalksa bile borcun ifası alacaklı için faydasız hale gelmişse sürekli imkansızlığın gündeme geleceği kabul edilmektedir. ${ }^{58}$

Uzun (belirsiz) süreli işyeri kira sözleşmeleri bakımından değerlendirme yapıldığında; koronavirüs salgınının geçici nitelikte olduğu göz önüne alınarak sürekli ifa imkansızlığının meydana gelmeyeceği, bu bağlamda dönemsel salgın önlemleri dolayısıyla işletme faaliyetlerinin kısıtlanması sebebiyle kira borcunun ödenmesi gecikmiş olsa ve zamanında yerine getirilemese de ifanın imkânsız hale geldiğinden söz edilemeyeceği kural olarak kabul edilmelidir. ${ }^{59}$ Öte yandan söz konusu değerlendirme yapılırken kira sözleşmesinin süresi, kiralanan taşınmazın konumu, durumu ve işletme amacı gibi faktörler nazara alınarak bir değerlendirme yapılmalıdır. Buna göre, mücbir sebep hali geçici olmasına rağmen sözleşmenin herhangi bir tarafından bu engelin ortadan kalkmasına kadar sözleşme ile bağlı kalmasının beklenemeyeceği (örneğin bir yerin belli bir mevsim ya da sezonda işletilmek üzere kiralanması ve kira süresinin büyük kısmını ya da tamamını içine alacak şekilde yasaklamalar öngörülmüş olması durumu gibi) hallerde akde tahammül süresinin dolduğu ileri sürülerek sürekli imkansızlık hükümlerinin uygulanması gündeme gelebilir. ${ }^{60}$ Böylesi bir durumda TBK 136. maddesi uyarınca sözleşmenin imkânsızlık nedeni ile sona erdiği ileri sürülebilecektir.

\section{KIRALANANIN AYIPLI HALE GELMESi}

TBK'nın 305. maddesine göre; kiralanan sonradan ayılı duruma gelirse kiracı, kiraya verenden ayıların giderilmesini veya kira bedelinden ayıla orantılı bir indirim yapılmasını ya da zararının

56 Yıldırım, s. 989; İrem Toprakkaya Babalık, "Korona Virüs Salgınının Kira Sözleşmelerine Etkisi, Geçici İfa İmkânsızlığı, İfa Güçlüğü ve Uyarlama”, Yayımlanmamış Makale, Lexpera, https://blog.lexpera.com.tr/korona-virus-salginininkira-sozlesmelerine-etkisi-gecici-ifa-imkansizligi-ifa-guclugu-ve-uyarlama-2/ (Son Erişim Tarihi: 11.05.2021). Geçici imkânsızlık halinde ifa tarihinin geçici imkansızlık hali ortadan kalkıncaya kadar ertelenmesi incelenirken bunun tarafların farazi ortak iradelerine uygun düşüp düşmeyeceğinin araştırılması gerektiği yönünde bkz. Oğuzman/ Öz, s. 570.

57 Yıldırım, s. 989; Aslı Makaracı Başak/ Seda Öktem Çevik/ Işılay Yörük, "Korona Virüsün İşyeri Kira Sözleşmelerine Etkisi”, Yayımlanmamış Makale, Lexpera, https://blog.lexpera.com.tr/koronavirus-tedbirlerinin-kira-sozlesmelerineetkisi/ (Son Erişim Tarihi: 11.05.2021).

58 Yıldırım, s. 989; Mustafa Dural, Borçlunun Sorumlu Olmadığı Sonraki İmkânsızlık (BK 117), İstanbul 1976, s. 100 vd.

59 Konunun kiralananın kullanımına başlanmış olup olmadığı ayrımına göre değerlendirildiği ayrıntılı bir inceleme için bkz. Yüce, Yayımlanmamış Makale.

60 Benzer yönde bkz. Göksoy, s. 9; Yüce, Yayımlanmamış Makale; Gündoğdu/Ural, Yayımlanmamış Makale. 
giderilmesini isteyebilir. Ancak, zararın giderilmesi istemi diğer seçimlik hakların kullanılmasını önlemez. Önemli ayıp durumunda kiracının sözleșmeyi fesih hakkı saklıdır.

Kiralananın sonradan ayıplı hale gelmesinden kiraya verenin sorumlu tutulması, kira sözleşmesinin sürekli borç ilişkisi yaratmasından ve buna bağlı olarak kiralananı sözleşmede amaçlanan kullanıma elverişli durumda bulundurma yükümlülüğünden kaynaklanmaktadır. ${ }^{61}$ Anılan ilkelere göre, kira sözleşmesinin kurulması ve kiralanan kiracıya teslimi ile kiraya verenin borcu ermeyip kiraya veren, kira süresince kiralananı sözleşmede öngörülen kullanma amacına elverişli halde bulundurmakla yükümlüdür. ${ }^{62}$ Öğretide kiralananın sonradan ayıplı hale gelmesine örnek olarak, kiralananın kullanıma elverişliliğini sonradan kısmen ya da tamamen ortadan kaldıran eksiklik veya bozukluklar verilmektedir. ${ }^{63}$

Koronavirüs salgınının kira sözleşmelerine etkilerini değerlendiren yazarlar genel olarak, ayıba karşı tekeffül hükümlerinin ve ayıba bağlanan sonuçların, somut olaya (salgın önlemlerine) uygun düşmemesi nedeniyle bu hükümlerin uygulanmaması gerektiği görüşündedir. ${ }^{64}$

Öğretide ileri sürülen görüşe rağmen, koronavirüsle mücadele için alınan kamusal önlemlerin kira sözleşmeleri bakımından etkileri kanaatimizce uygun düştügü ölçüde çevresel (manevi) ayıp kapsamında değerlendirilebilir. Alman hukukunda çevresel ayıp olarak ele alınan kavram, Türk hukukunda manevi ayıp kapsamında ele alınmaktadır. ${ }^{65}$ Buna göre; Alman hukukunda ileri sürüldüğü üzere, kiralanandaki ayıbın yalnızca kiralananın fiziksel koşullarına ilişkin olması gerekmediği, bir diğer ifadeyle, kiracının kiralananı sözleşmede öngörülen kullanım amacına uygun surette kullanmasını manevi açıdan güçleştiren olay ve durumların da ayıp kapsamında değerlendirilebileceği kabul edilmelidir. ${ }^{66}$

Manevi ayıp dolayısıyla kiraya verenin ayıba karşı tekeffül sorumluluğunun söz konusu olması için kiracının kullanıma bağlı umduğu edim yararına ulaşmasını engelleyen nitelikte bir problemin mevcudiyeti yeterlidir. Bu bağlamda bir değerlendirme yapılırken öncelikle kira sözleşmelerinde çevresel koşulların değişmesi ve buna göre kiralananın kullanımının etkilenmesine ilişkin açık ya da zımni nitelikte bir düzenlemenin varlığı araştırılmalıdır. Sözleşmenin başındaki çevresel koşullardan

61 Cevdet Yavuz/ Faruk Acar/ Burak Özen, Borçlar Hukuku Dersleri (Özel Hükümler), 16. Baskı, İstanbul 2019, Beta Yayınc1lik, s. 253.

62 Yavuz/Acar/Özen, s. 253.

63 Haluk Tandoğan, Borçlar Hukuku Özel Borç İlişkileri C.1/2, 4. Baskı, İstanbul 2008, Vedat Kitapçıllk, s. 114; Fahrettin Aral/ Hasan Ayrancı, Borçlar Hukuku Özel Borç İlişkileri, 13. Baskı, Ankara 2020, Yetkin Yayıncılık, s. 227; Yavuz/Acar/ Özen, s. 196.

64 Bilgin Yüce, Yayımlanmamış Makale; Gündoğdu/Ural, Yayımlanmamış Makale; Makaracı Başak/ Öktem Çevik/ Yörük, Yayımlanmamış Makale.

65 Çevresel ayıp (Umweltfehler) meselesinin ele alındığı Federal Mahkeme kararları için bkz. BGH, Urteil vom 01.07.1981 - VIII ZR 192/80, NJW 1981, s. 2405; BGH, Urteil vom 23.9.2009 - VIII ZR 300/08, NJW 2009, Rz. 12 vd.; BGH, Urteil vom 21.9.2005 - XII ZR 66/03, NJW 2006, s. 899.

66 Mustafa Alper Gümüş, "Yeni" 6098 Sayll Türk Borçlar Kanuna Göre Kira Sözleşmesi, 2. Baskı, İstanbul 2012, Vedat Kitapçlık, s. 102; M. Murat İnceoğlu, Kira Hukuku Cilt 1, İstanbul 2014, On İki Levha Yayıncilık, s. 130; Mehmet Üçer / Nedim Meriç, "Kiracının Tacir Olması Durumunda Kiraya Verenin Ayıptan Sorumluluğunun Kapsamı”, Dicle Üniversitesi Hukuk Fakültesi Dergisi, 2014, Cilt: 19, Sayı: 30-31, s. 413. 
sayılabilecek müşteri potansiyeli ve erişilebilirliği hususu, kira sözleşmesinin başında taraflarca tartışılmış ve kiraya veren işyerinin müşteri hacmine ilişkin olarak kiracıya bir taahhüt vermişse, salgınla mücadele kapsamında alınan kamusal önlemlerin, kiralananın kullanım amacını ve müşteri potansiyelini etkilediği ölçüde TBK 305. maddesi uyarınca kiralananı ayıplı hale getirdiği iddiası dinlenebilir. Taraflar arasındaki kira sözleşmesinde çevresel koşullara ilişkin açık ya da zımni bir düzenleme bulunmasa bile, Alman hukukunda yargı kararları ve öğreti görüşlerinde ileri sürüldüğü üzere kiralananın sözleşmede belirlenen kullanım amacından hareket edilmesi mümkündür. ${ }^{67} \mathrm{Bu}$ hususta yukarıda sunulan Alman mahkeme kararlarındaki kıstaslar Türk hukuku bakımından da yol gösterici olabilecek niteliktedir. ${ }^{68}$ Kiralan taşınmazın pandemiyle mücadele kapsamında öngörülen kamusal sınırlamalar dolayısıyla kullanım amacına uygun şekilde kullanılamaması durumunda kiralanın ayıplı hale geleceği kabul edilebilir. Bu bağlamda bir değerlendirme meselesi olmakla birlikte, salgın hastalık dolayısıyla öngörülmüş kamusal önlemler ve kullanım engelleri sebebiyle kiracı, işyeri faaliyetlerinin kısıtlandığını ve işyerinin sözleşmede öngörülmüş olan kullanım amacına uygun şekilde/ gereği gibi kullanılamadığını ve dolayısıyla, kiralananın ayıplı hale geldiğini ileri sürebilir.

Salgınla mücadele için alınan önlemler dolayısıyla kiralananın ayıplı hale gelmesi halinde kiracının hangi seçimlik hak ya da hakları, hangi kapsamda kullanabileceğinin de değerlendirilmesi gerekir. İlk olarak, TBK’nın 307. maddesi gereğince kiracının kira bedelinde indirim hakkını kullanması bakımından aranan kıstas, ayıbın kiralananın kullanımını etkilemesi durumudur. Buna göre, manevi ayıp dolayısıyla kira bedelinde indirim hakkının ileri sürülebilmesi için ayıbın kiracının kullanıma bağlı umduğu edim yararına ulaşmasını engelleyen nitelikte olması yeterli olacaktır. $\mathrm{Bu}$ durumda salgın önlemleri dolayısıyla işletme faaliyetleri kısıtlanan ve sözleşmede öngörülen işletme amacını gerçekleştiremeyen işyerleri bakımından kiralananın ayıplı hale geldiği kabul edilebilir ve - somut olayın koşulları ve kira sözleşmesinin tüm özelliklerine göre - ayıp oranında bedelde indirim yapılabilir. İndirimin oranı bakımından somut olayı inceleyen hâkim; kiralananın yeri ve konumu, kiracının önlemler sebebiyle yaşadığı gelir kaybı, bu kaybı telafi edecek herhangi bir yardım alıp almadığı gibi hususları değerlendirerek somut olayın koşulları ve taraflar arasındaki menfaat dengesini gözeterek bir sonuca ulaşmalıdır. Diğer seçimlik haklar bakımından ise ayıbın niteliği ve etkileri ile işyeri kira sözleşmelerinin niteliği itibariyle ayıbın giderilmesinin istenmesi ya da kiralananın ayıpsız benzeri ile değişmesi talepleri uygulama alanı bulamayacaktır. Alınan önlemler kamu gücüne dayanılarak öngörülmüş olmakla ayıbın giderilmesi imkânı bulunmamaktadır. ${ }^{69}$ Bununla birlikte; salgın dolayısıyla alınan önlemlerin kiralanan üzerindeki etkisi değerlendirilerek önemli ayıbın varlığının kabul edilmesi halinde kiracının, TBK’nın 306/2 maddesi uyarınca uygun bir süre vermek suretiyle sözleşmeyi feshedebileceği de kabul edilmelidir. Bir diğer ifadeyle; ayıbın etkileri nazara alınarak, kiracının mevcut (değişen) çevresel şartlarda kira sözleşmesine devam etmesinin kendisinden beklenemeyeceği durumda kira sözleşmesi feshedilebilir.

Son olarak TBK’nın 331. maddesi de bu değerlendirme çerçevesinde ele alınabilir. Söz konusu hüküm uyarınca, kira sözleşmesinin taraflardan her biri, kira ilişkisinin devamını kendisi için

67 Bu hususta detaylı açıklamalar için bkz. Yukarıda I.B. bölümü.

68 Yukarıda I.D. bölümü s. 12 vd.

69 Karş. Bilgin Yüce, Yayımlanmamış Makale. 
çekilmez hâle getiren önemli sebeplerin varlığı durumunda, sözleşmeyi yasal fesih bildirim süresine uyarak her zaman feshedebilir ki somut olayın şartlarına göre salgın önlemlerinin de bu kapsamda değerlendirilmesi mümkün olabilir.

\section{E. IŞYERI KIRA SÖZLEŞMELERININ DEĞiŞEN KOŞULLARA UYARLANMASI TALEBi}

Alman hukukunda ileri sürüldüğü üzere; Türk hukuku bakımından da Covid-19 salgını dolayısıyla alınan önlemler dolayısıyla işyeri faaliyetlerinin durması ya da büyük ölçüde askıya alınması, bir diğer deyişle "aşırı ifa güçlüğü" nedeniyle sözleşmenin değişen koşullara uyarlanması iddiası TBK 138. maddesi kapsamında ileri sürülebilir. ${ }^{70}$

Uyarlamanın gündeme gelebilmesi için geçerli bir şekilde kurulmuş olan sözleşmeden doğan bir borcun sonradan ortaya çıkan bir sebeple ifasının aşırı güçleşmesi ve henüz borcunu ifa etmemiş ya da ifa etmekle birlikte buna ilişkin haklarını saklı tutmuş olan borçlunun sözleşmenin yeni koşullara göre güncellenmesini istemesi gerekir. ${ }^{71}$

Uyarlamanın gerçekleşebilmesi için aranan kıstas, hükmün gerekçesinde ve Alman hukukunda da ileri sürülen "işlem temelinin çökmesi” durumudur. Salgın/ pandemi koşulları ve buna bağlı olarak alınan sıkı önlemlerin de bu kapsamda değerlendirilebileceği kabul edilmelidir. ${ }^{72}$ İşlem temelinin çökmesinden söz edilmesi için sözleşmenin temelini oluşturan koşullar, sözleşmenin kurulmasından sonra önemli ölçüde ve öngörülemez şekilde değişmiş olmalıdır. ${ }^{73}$ Sözleşme koşullarının önemli ölçüde değişmesi ile kastedilen şudur: Sözleşme tarafları bu değişiklikleri öngörmüş olsalardı sözleşmeyi ya hiç yapmayacaklardı ya da başka bir içerikle yapacaklardı. ${ }^{74}$

Bu bağlamda bir değerlendirme meselesi olmakla birlikte, Alman hukukunda öngörülen karinedeki benzer bir bakış açısıyla bulaşıcı hastalığın (Covid-19 pandemisinin) hayatın olağan akışı içinde beklenmedik ve olağanüstü bir olay olarak değerlendirilmesi mümkündür. ${ }^{75}$ Buna göre, bulaşıcı hastalık nedeniyle borçlunun edimini ifa etmesi kendisi için aşırı derecede güçleşmiş olabilir. Kira sözleşmeleri bakımından da kira bedelini düzenli ödeme yükümlülüğü altında bulunan ancak pandemiyle mücadele önlemleri neticesinde işletmesi kapatılan veya faaliyeti önemliölçüde sınırlanan kiracı bakımından bu yükümlülügün kendisi aleyhine önemli ölçüde değiştiği ve sözleşmenin kurulduğu andaki şartlarla sözleşmeye devam etmesinin kendisinden beklenemeyeceği kural olarak ileri sürülebilir. Ancak burada da - Alman hukukunda ileri sürüldügü şekilde - somut olay bazında değerlendirme yapılması ve korona önlemleri dolayısıyla ortaya çıkan şartların uyarlamayı haklı çıkarıp çıkarmayacağının tespit edilmesi gerekir. Bu kapsamda; salgın önlemlerine ve işletme

70 Dural, s. 101.

71 Ahmet Kılıçoğlu, Yayımlanmamış Makale.

72 Ahmet Kılıçoğlu, Yayımlanmamış Makale.

73 Oğuz, s. 1280.

74 Oğuz, s. 1280.

75 Bu yönde bkz. Oğuz, s. 1280 vd.; Yıldırım, s. 990 vd.; Kayış, s. 5 vd.; Yüce, Yayımlanmamış Makale; Baysal/ Uyanık/ Yavuz, Yayımlanmamış Makale; Gündoğdu/ Aral, Yayımlanmamış Makale. 
faaliyetleri kısttlanmasına rağmen, kiracı borçlu - örneğin online satış yoluyla veya kısıtlı fiziki alışverişe rağmen - gelir kaybı yaşamadıysa (ya da yaşanan gelir kaybı katlanılabilir bir düzeydeyse) bu durumda ifanın aşırı derecede güçleştiği ve bu bağlamda, işlem temelinin çöktüğünden söz edilemeyecektir. Öte yandan, örneğin kuaför işleten bir kiracı, salgın önlemleri dolayısıyla işyerini hiç işletemiyor ya da çok sınırlı düzeyde işletiyorsa ve bu nedenle de önemli ölçüde gelir kaybına uğramış ve kira bedelini ödeyemiyor durumda ise bu durumda işlem temelinin çöktüğü iddiası ileri sürülebilmelidir.

Son olarak meselenin değerlendirildiği ve yukarıda sunulan güncel Yargıtay kararında (3. Hukuk Dairesi 17.11.2020 tarih ve E. 2020/2910 - K. 2020/6680 sayll karar1) salgın hastalık mücbir sebep olarak değerlendirilmiş ve uyarlama bakımından sözleşmenin şartlarının değiştiğinin ve taraflardan biri bakımından aşırı güçleştiğinin incelenmesi gerektiği hükme bağlanmıştır. Buna göre salgın hastalık gibi bir mücbir sebebin ortaya çıkması durumunda sözleşmenin yapıldığı sıradaki olguların, borçludan ifanın istenmesini dürüstlük kuralına aykırı düşürecek derecede borçlu aleyhine değişmiş olup olmadığının incelenmesi gerektiği ifade edilmiştir.

\section{F. YARGILAMADA GÜNCEL DURUM}

Salgın önlemleri sebebiyle ortaya çıan yeni hukuki koşullar ve bunların beraberinde getirdiği sorunlar yargı alanına da taşınmaya başlamış olup bu anlamda halihazırda pandemiyle mücadele önlemlerinin kira sözleşmeleri bakımından etki ve sonuçlarını değerlendiren bir Bölge Adliye Mahkemesi kararı, içtihatlar arasına girmiş bulunmaktadır.

Bursa Bölge Adliye Mahkemesi 4. Hukuk Dairesi, 28.09.2020 tarih ve E. 2020/1103 - K. 2020/1008 sayılı kararında; davanın, pandemi süreci nedeniyle iş hacminde meydana gelen düşüş nedeniyle TBK’nın 138. maddesinde ön görülen şartların oluşması nedeniyle dava konusu mecurun aylık kirasının Covid-19 salgının etkili olduğu dönem boyunca geçerli olmak üzere uyarlanması ve Covid-19 salgının etkili olduğu dönem boyunca geçerli olmak üzere ödenmesi konusunda ihtiyati tedbir kararı verilmesi istemine ilişkin olduğunu belirterek kiranın uyarlanması için açılan davada mahkemece davacı kiracının yapmış olduğu işin niteliği ve tüm koşullar ile taraflarca sunulan deliller göz önünde bulundurularak kiranın mahkemece takdir edilecek bir miktar üzerinden ödenmesi hususunda ihtiyati tedbir kararı verilmesi gerektiğini, ancak bu tedbir kararının mahkemece belirli aralıklarla veya tarafların müracaatı üzerine değerlendirilerek durum ve koşulların değişmesi halinde kaldırılması veya belirlenen yeni bir miktar üzerinden devam etmesine karar verilmesi gerektiğini ifade etmiştir. Yüksek Mahkemece, somut olayda kiracının restoran olarak işlettiği kiralananda her ne kadar paket servis yöntemi ile işine devam etmiş ise de süreç ve alınan tedbirlerin davacının iş hacminde belirli etkilerinin olabileceği değerlendirilerek ihtiyati tedbir talebinin kabul edilmesi gerektiği benimsenmiş olup salgın süresince restoran olan iş yerlerinin etkilenme sürecinin aylara göre değişkenlik gösterdiği ve bu etkilerin ne kadar daha devam edeceğinin belli olmadığı göz önünde bulundurularak ihtiyati tedbirin 6 ayda bir mahkemece gözden geçirilmesi ve yeni durumlara göre kaldırılması veya arttırılıp azaltılması hususlarında karar verilmesi gerektiği kabul 
edilmiştir. En nihayetinde, 4. Hukuk Dairesi, yapılan yargılama sonunda taraflar arasında imzalanan kira sözleşmesi sırasında yaşanan pandemi sürecinin öngörülemeyen bir durum ve ihtiyati tedbir kararı verilmemesi halinde ciddi bir zarar oluşturacağını (temerrüt nedeniyle tahliye gibi) belirterek, ihtiyati tedbir talebinin kabulüne ve karar tarihinden itibaren işleyecek kiraların (\%50 azaltılarak) aylık 11.500,00 TL olarak ödenmesi hususunda ihtiyati tedbir konulmasına karar vermiştir.

$\mathrm{Bu}$ anlamda Yüksek Daire, taraflar arasındaki menfaat dengesini bir hareket noktası olarak değerlendirmiş ve ihtiyati tedbire karar verilmemesi durumunda kiracının dava sonuna kadar kira bedelini tam olarak ödemek zorunda kalacağını, pandemi döneminde iş yerinin kapalı olması nedeniyle hiçbir gelir elde edemeyen davacının söz konusu kira bedelini ödeyemeyeceğini ve bunun sonucunda da tahliyesinin söz konusu olabileceğini, böylesi bir durumda da davanın sonunda verilebilecek uyarlama kararının davacıya hukuki koruma sağlamayacağı gerekçeleriyle ihtiyati tedbir kararı vermiştir. Bu anlamda Mahkeme, yine menfaat dengesini nazara alarak, davacının ihtiyati tedbir kararı ile belirlenen kira bedelini ödemesinin, davalı bakımından telafisi mümkün olmayan bir zarar doğurmayacağı kanaatine varmıştır.

\section{G. DEĞERLENDIRME}

Covid-19 pandemisi nedeniyle günlük hayatın her alanında her geçen gün dramatik değişiklikler olmakta ve toplumsal hayat, hemen hemen dünyanın her yerinde - salgının seyrine göre - büyük ölçüde kısıtlanmaktadır. Söz konusu kısıtlamalar, global ekonominin önemli bir parçası olan gayrimenkul endüstrisini de olumsuz yönde etkilemiş ve pek çok ülke bunların toplumsal hayatta kullanımına yönelik ciddi kapanmalar öngörmüştür. Söz konusu kullanım kısıtlamaları ve - bazı durumlarda süresiz şekilde öngörülmüş - kapanma kararları; yeme-içme yerleri, tiyatro, sinemalar, gece kulüpleri, eğlence yerleri, spor stüdyoları gibi kamusal alanlar ve bunların kira sözleşmelerinin akıbetleri bakımından da hukuki soru ve sorunları akıllara getirmektedir.

Meselenin çok yeni ve günden güne farklı yön ve gelişmelere evirilebilir olması nedeniyle, söz konusu kamusal kısıtlamaların kira sözleşmeleri ve kiracının konumu (kira bedeli ödeme borcunun akıbeti) bakımından doğuracağı hukuki sonuçlara ilişkin farklı hukuki görüşler ileri sürülmektedir. Yukarıda ifade edildiği üzere; çeşitli görüşler arasında en dikkat çeken hukuki dayanaklar geçici imkansızlık, kiralananın ayıplı hale gelmesi ve kira sözleşmesinin aşırı ifa güçlüğü nedeniyle uyarlanması iddialarıdır. İfade etmek gerekir ki anılan hukuki kurumlar somut olayın şartlarına göre savunulabilir ve farklı gerekçelerle uygulanabilir ya da reddedilebilir durumdadır.

Yukarıda detaylarıyla sunulan Alman Federal Mahkemesi’nin (Reichsgericht) "dans lokali” kararına konu olan somut durum, günümüzde koronavirüs pandemisi dolayısıyla getirilen kamusal sınırlamalar ve bunların işyerleri bakımından doğurduğu sonuçlar açısından büyük benzerlikler taşımaktadır. Federal Mahkeme’nin haklı olarak ileri sürdüğü şekilde; kamusal kısıtlamalar dolayısıyla işyeri faaliyetleri kısıtlanan kiracı işletmeciler ve bunların kira bedelini ödeme borcunun akıbetine ilişkin olarak, kısıtlama ile işletme faaliyeti arasındaki ilişki değerlendirilmelidir. Buna göre; kısıtlamanın getirdiği somut durum, sözleşme konusu faaliyetin hiç yerine getirilememesine 
ya da çok sınırlı şekilde icra edilebilmesine sebebiyet vermişse kiralananın ayıplı hale geldiği ve ayıp oranında kira bedelinde indirim yapılabileceği kabul edilmelidir.

Söz konusu kamusal sınırlamalar her ne kadar yasalar ve diğer düzenleyici işlemlerin çizdiği sınırlar ölçüsünde uygulamaya konsa da sınırlamaların kiralananın kullanımını önemli ölçüde kötüleştirmiş olup olmadığı ve süresi ile kiracı bakımından iş ve gelir kaybına yol açıp açmadığı, sınırlamalar ve gelir kaybı dolayısıyla devlet desteği alınıp alınmadığı vs. nazara alınarak bir değerlendirme yapılmalıdır. Buna göre; örneğin bir restoran sahibi, salgın kısıtlamaları sebebiyle her ne kadar işyerinde hizmet veremese de gel-al ve paket servis ile hizmet vermeye devam etmiş ve bu süreçte önemli ölçüde bir gelir kaybı yaşamamış, iş hacmi azalmamışsa bu durumda kiralananın kullanım amacı etkilenmemiş sayılmalı ve ayıp iddiası kabul görmemelidir. Öte yandan yerinde hizmet dışında alternatif bir hizmet sunma imkânı bulunmayan kuaförler açısından durum tam tersidir. Kısıtlama ve kapatmalar ile kuaför faaliyeti yerine getirilemeyeceğinden (ya da ancak çok sınırlı şekilde gerçekleşebileceğinden), kullanım amacının önemli ölçüde etkilendiği ve kira bedelinde indirim hakkının kullanılabileceği kabul edilmelidir. Ayıbın kabulü halinde de kira bedelinde indirimin hangi oranda yapılacağı hususu nazara alınmalıdır ki bu oran, objektif kriterlere göre (örneğin sınırlamaların süresi, sınırlamalar dolayısıyla yaşanan iş kaybı vs.) belirlenecektir. ${ }^{76}$ Indirim oranı bakımından, kiralayanın kişisel koşulları nazara alınmamaktadır, çünkü bu koşulların kira bedelinin belirlenmesinde de bir rolü bulunmamaktadır. ${ }^{77}$

Hukukumuzda kabul edilen sözleşmeye bağlılık (Ahde Vefa-Pacta Sund Servanda) ve sözleşme serbestliği ilkelerinin bir istisnası olarak kabul edilen işlem temelinin çökmesi ve buna dayalı uyarlama istemi, işyeri kira sözleşmeleri bakımından nazara alınabilir. Sözleşmenin değişen koşullara uyarlanması ya da dönme hakkının kullanılması, şu dört koşulun birlikte gerçekleşmesine bağlıdır: TBK m. 138 hükmü uyarınca uyarlama isteminin kabul edilebilmesi için sözleşmenin yapıldığı sırada, taraflarca öngörülmeyen ve öngörülmesi de beklenmeyen olağanüstü bir durum ortaya çıkmış ve bu durum borçludan kaynaklanmamış olmalıdır. Bu durum, sözleşmenin yapıldığ sırada mevcut olguları, kendisinden ifanın istenmesini dürüstlük kurallarına aykırı düşecek derecede borçlu aleyhine değiştirmiş olmalıdır. Son olarak borçlu, borcunu henüz ifa etmemiş veya ifanın aşırı ölçüde güçleşmesinden doğan haklarını saklı tutarak ifa etmiş olmalıdır.

Türk hukuku bakımından da Almanyada öngörülen yasal karine yol gösterici olmalı ve Covid-19 salgını dolayısıyla gerçekleştirilen işyeri kapatmalarının kira sözleşmesinin tarafları arasında işlem temelinin çökmesine sebebiyet verdiği ve TBK 138. maddesi bağlamında bunun da sözleşmenin değişen koşullara uyarlanmasına imkân sağlayabileceği kabul edilmelidir. Bir diğer ifadeyle; Alman hukukunda yeni yasal karine ile öngörüldüğü üzere, salgın dolayısıyla alınan kamusal kararlar ve bunların neticesinde ortaya çıkan yeni ekonomik koşulların ilgili hükümde belirtilen "sözleşmenin yapıldığı sırada, taraflarca öngörülmeyen ve öngörülmesi de beklenmeyen olağanüstü bir durum" kapsamında değerlendirilmesinin ve öngörülmezlik şartının gerçekleştiğinin kabulü gerekir.

76 BGE 91 II $105 \mathrm{vd}$.

77 Semaine judiciaire 1986, s. 199. 
Tacirler bakımından öngörülmezlik şartının gerçekleşmeyeceği ve bu nedenle uyarlama talebinin kabul görmeyeceği yönünde çok sayıda karar $^{78}$ veren Yargıtay’n bu görüşünün aksine Alman hukukunda yürürlüğe giren yasal karine, sözleşmenin taraflarının nitelikleri (bir diğer ifadeyle tacir olup olmadıkları) bakımından bir değerlendirme yapmamakta, salgını başlı başına öngörülemez bir durum olarak değerlendirmektedir. Öte yandan, TBK 138. maddesinin tacirlere de uygulanabileceğini kabul etmekte beraber, basiretli iș adamı gibi hareket etme yükümlülüğünün öngörülmezlik şartının gerçekleşme ihtimalini azalttığını savunan öğreti görüşü ve Yargıtay kararları karşısında da ${ }^{79}$ Alman hukukunda öngörülen yeni karinede bunun bir değerlendirme kıstası olarak yer almadığı vurgulanmalıdır. Yukarıda değinilen Bursa BAM 4. Hukuk Dairesi kararında da tarafların tacir niteliği nazara alınmaksızın, yaşanılan salgın hastalık sürecinin olağanüstü bir durum olduğu ve taraflarca öngörülemeyeceğinin açık olduğu ve genel olarak salgın hastalık sürecinin 138. maddede belirtilen olağanüstü durum olarak kabul edilmesi gerektiği belirtilmiştir.

İşlem temelinin kısmen veya tamamen çökmesi durumunda sözleşmenin yeni şartlara uyarlanmasını ileri süren emprevizyon teorisini benimseyen Yargitay da 13. Hukuk Dairesỉnin 10.03.2010 tarih ve 2010/188 E. - 2010/2991 K. sayılı ilamında şu ifadelere yer vermiştir: "Sözleşme yapıldığı andaki karşılıklı edimler arasında mevcut olan denge, sonradan şartların olağanüstü değişmesiyle büyük ölçüde taraflardan biri aleyhine katlanılamayacak derecede bozulabilir. İște bu durumda sözleşmeye bağll1ık ve sözleşme adaleti ilkeleri arasında bir çelişki hasıl olur ve artık bu ilkeye sıkı sıkıya bağlı kalmak adalet, hakkaniyet ve objektif hüsnüniyet (M.K. 2., 4. md) kaidelerine aykırı bir durum yaratır hale gelir. Hukukta bu zttlık beklenemeyen hal şartı-sözleşmenin değişen şartlara uydurulması ilkesi ile giderilmeye çalışılmaktadır. Beklenmeyen hal kuramının açıklanması şöyle yapılmaktadır. Akit yapıldığı sırada mevcut bulunan şartlar önemli surette değişmiş ise taraflar akide bağlı olmamalıdır. Buna beklenmeyen hal şartı (Clausa Rebus Sic Stantibus) denmektedir. $\mathrm{Bu}$ görüş öğretide "Emprevizyon Teorisi" adıyla anılmaktadır. Öğretide sözleşmenin yapıldığı zamandaki durumların değişmemesi şartıyla yapıldığı varsayılır. Akitlerin ifasının şartların değişmesine bağlayan fikri çok gerçeğe uygun değil ise de Ahde Vefa prensibine kesin ve sıkı sıkıya bağllı̆ğında her zaman adil olmadığı görülmektedir. Bugün İsviçre’de Türk Hukukunda çoğunlukla dayanılan esas dürüstlük kuralı uyarınca çözüm bulunmasıdır. Hukukumuzda mehaz kanunundaki uygulamalar doğrultusunda Medeni Kanun'un 2. maddesinden de esinlenmek suretiyle hem Clausula Rebus Sic Stantibus ilkesine hem de işlem temelinin çökmesi kuramını uygulamak suretiyle uyarlama davalarının görülebilir olduğunu benimsemiştir. İşlem temelinin çökmesi kavramının uygulanabilmesi için sonradan meydana gelen değişikliklerin önceden teşhis ve tahmin edilememiş olmasi gerekir. Her talep vukuunda sözleşmeyi değişen hal ve şartlara uydurmak mümkün değildir. Aksi halde özel hukuk sistemimizde geçerli olan "irade özgürlüğü", "sözleşme serbestliği” ve

78 Yargitay 15. HD., 2.6.1987 T., E. 26, K.2433; YHGK 07.5.2003 E. 2003/13-332, K. 2003/340; YHGK 15.10.2003 E.2003/13599 K. 2003/599; Yargitay 13. HD. 28.6.2004, E. 2004/2610, K. 2004/10082, Yargitay 13. HD. 23.9.2003, E. 2003/5912, K. 2003/10490; Yargitay 13. HD. 3.7.2003, E. 2003/4607, K. 2003/9022; Yargitay 13. HD. 10.6.2003, E. 2003/3622, K. 2003/7636. Söz konusu kararlara rağmen; TBK m. 138'de yer alan düzenlemenin genel nitelikli hüküm olması ve bu nedenle de ticari ilişkilere de uygulanacak olması yönünde bkz. İnceoğlu, s. 166.

79 Baysal, N. 420; Yargitay 3. HD., E. 2017/261, K. 2017/781, T. 21.02.2017; bkz. Yargitay 3. HD., E. 2017/4139, K. 2018/9876, T. 10.10.2018; Yargitay 19. HD., E. 2016/17473, K. 2017/3673, T. 11.5.2017; Samsun BAM, 6. HD., E. 2019/2121, K. 2019/2192, T. 10.5.2019. 
"Sözleşmeye bağlılık” ilkelerinden sapma tehlikesi ortaya çıkar. Sözleşmeye müdahale müessesesi istisnai, tali (ikinci derece de) yardımcı niteliktedir. Sözleşmeye bağlılık ve saygı esastır.”

Anılan ilke ve kıstaslar kapsamında değerlendirme yapılması zorunlu olup esas prensibin sözleşmeye bağlılık olduğu, sözleşmenin değişen şartlara uyarlanmasının ancak istisnai hallerde dar kapsamda yorumlanacak şartların gerçekleşmesi halinde gündeme gelebileceği unutulmamalıdır. ${ }^{80}$ Esas ilke bu olmakla birlikte, sözleşme taraflarının menfaat dengesi her zaman odak noktada tutularak salgın önlemleri neticesinde meydana gelen ekonomik koşulların kiracı bakımından doğurduğu ve doğuracağı sonuçlar göz önüne alınmalıdır. Bu bağlamda, öngörülmezlik şartının gerçekleştiği kabul edilerek meydana gelen yeni koşulların kiracı bakımından bir aşırı ifa güçlügü yaratıp yaratmadığı değerlendirilmelidir. Bu kapsamda, sözleşmeye mevcut haliyle devam etmesinin kiracıya ekonomik açıdan büyük zarar vereceğinin ya da kiracının ekonomik mahvına sebep olacağının kiracı tarafından ispat edilmesi halinde aşırı ifa güçlüğünün gerçekleştiğinin kabulü gerekir. Buna göre; somut olay bağlamında inceleme yapılması gerekmekte olup anılan şartın gerçekleşip gerçekleşmediğinin tespiti bakımından satışlardaki düşüş oranı, e-ticaret imkanının bulunup bulunmadığı, varsa bu yolla sağlanan gelir düzeyi, kısa süreli çalışma yoluyla tasarruf edilen harcamalar ve diğer tasarruf kalemleri gibi faktörler bu incelemede nazara alınmalı ve sözleşmeye mevcut haliyle devam etmesinin kiracıdan beklenip beklenemeyeceğine karar verilmelidir. Burada da sözleşmenin ayakta tutulması ilkesinden yola çıkılarak sözleşmenin uyarlanması kira bedelinde indirim olarak değerlendirmeye alınmalı, ancak çok istisnai hallerde (örneğin salgın önlemleri nedeniyle işletmenin süresiz olarak kapatılması ve tekrar ne zaman açılacağının tamamen öngörülemez olması, gelir düzeyinin öngörülemez bir süre için sıfıra inmesi durumları vs.) ultima ratio olarak sözleşmenin feshedilmesi yoluna gidilmelidir.

\section{SONUÇ}

Covid-19 (Coronavirus Sars-CoV-2) salgınının Çin’in Vuhan eyaletinde başlayarak hızla tüm dünyaya yayılması akabinde hemen her ülke salgının yayılmasını engellemek amacıyla kamusal hayatı önemli ölçüde etkileyen ve kısıtlayan bir dizi önlem alma yoluna gitmiştir. Söz konusu yasak ve kısıtlamalar, günlük hayatın her alanında olduğu gibi bilhassa hukuk ve ekonomi alanında çarpıcı sonuçlar doğurmaktadır.

Bu çalışmada inceleme konusu yapılmış salgın önlemlerinin bilhassa uzun süreli işyeri kira sözleşmeleri bakımından doğurduğu ve doğuracağı hukuki sonuçlara yönelik olarak Alman hukukunda yürürlüğe giren ve yukarıda detaylarıyla sunulan yeni yasal karine, önlemlerin doğurduğu koşullar nedeniyle menfaat dengesi bilhassa kiracılar aleyhine önemli ölçüde bozulan kira sözleşmeleri bakımından yol gösterici olabilecek niteliktedir. Söz konusu yasal düzenleme, salgın nedeniyle sözleşmenin değişen koşullara uyarlanmasına yönelik olarak beklenmeyen/ olağanüstü bir durumun gerçekleştiğini karine olarak kabul etmekle beraber, uyarlama talebinin kabul görmesi için kanunun öngördüğü diğer şartlarının gerçekleşmesi gerektiğini belirtmektedir. Bununla birlikte, uyarlama talebini sıklıkla

80 Baysal, N. 488; Özlem Tüzüner/ Kerem Öz, “Aşırı İfa Güçlüğüne İlişkin İçtihat İncelemesi”, Ankara Barosu Dergisi, 2015; Sayı:3, s. 440 vd. 
öngörülmezlik şartının gerçekleşmediğinden bahisle reddeden yerleşik Yargıtay kararları karşısında Alman hukukundaki yeni yasal karine bir bakış açısı ve dayanak noktası teşkil etmelidir. Öte yandan, salgın dolayısıyla alınan önlemlerin, geçici imkansızlığa yol açtığı veyahut da kiralananı ayıplı hale getirdiği görüşü de kabul görebilir bir hukuki gerekçe olup Alman hukukundaki emsal "dans lokali” kararı çerçevesinde ve hatta çevresel (manevi) ayıp kapsamında bir değerlendirme yapılarak da ayıp iddiasının kabul görmesi gündeme gelebilecektir.

\section{KAYNAKÇA}

Aral Fahrettin/ Ayrancı Hasan, Borçlar Hukuku Özel Borç İlişkileri, 13. Baskı, Ankara 2020, Yetkin Yayıncılık.

Baysal Başak, Sözleşmenin Uyarlanması, TBK m. 138-Aşırı İfa Güçlüğü, 3. Baskı, İstanbul 2019.

Baysal Başak/ Uyanık Murat/ Yavuz M. Selim, “Koronavirüs 2019 (COVID-19) ve Sözleşmeler”, Yayımlanmamış Makale, Lexpera, https://blog.lexpera.com.tr/koronavirus-2019-ve-sozlesmeler/ (Son Erişim Tarihi: 11.05.2021).

Bilgin Yüce Melek, "Koronavirüs Salgını Nedeniyle Hükümet Kararıyla Kapatılan İşyerlerinin Kira Sözleşmelerinin Akıbetinin Değerlendirilmesi”, Yayımlanmamış Makale, Lexpera, https://blog.lexpera. com.tr/koronavirus-salgini-nedeniyle-hukumet-karariyla-kapatilan-isyerlerinin-kira-sozlesmelerininakibetinin-degerlendirilmesi/ (Son Erişim Tarihi: 11.05.2021).

Dural Mustafa, Borçlunun Sorumlu Olmadiğı Sonraki İmkânsızlı (BK 117), İstanbul 1976, s. 101.

Eren Fikret, Borçlar Hukuku Genel Hükümler, Ankara 2020, 25. Baskı.

Gewerberaummiete Kommentar, 2. Auflage 2019, Hrsg. Hartmut Guhling, Peter Günter.

Göksoy Yaşar Can, "Basiretli İş Adamı Gibi Hareket Etme Yükümlülüğü (TTK m. 18) Bağlamında Covid-19 Pandemisinin Tacirlerin Sözleşmeden Doğan Yükümlülükleri Üzerindeki Etkileri”, Yaşar Hukuk Dergisi, Cilt:2, Sayı:2 Özel Sayı, 2020, s. 3.

Gümüş Mustafa Alper, "Yeni” 6098 Sayılı Türk Borçlar Kanuna Göre Kira Sözleşmesi, 2. Baskı, İstanbul 2012, Vedat Kitapçllık.

Gündoğdu Fatih, Borca Aykırılık Hallerinden Kusurlu İfa İmkansızlı̆̆ı ve Hukuki Sonuçları, İstanbul 2014.

Gündoğdu Fatih/ Ural Nihal, "Koronavirüs (COVID-19) Tedbirlerinin Kira Sözleşmelerine Etkisi”, Yayımlanmamış Makale, Lexpera, https://blog.lexpera.com.tr/koronavirus-tedbirlerinin-kirasozlesmelerine-etkisi/ (Son Erişim Tarihi: 11.05.2021).

Günter Peter, “Der Einfluss öffentlich-rechtlicher Verpflichtungen auf mietvertragliche Vereinbarungen”, NZM 2016, s. 569.

Häublein Martin/ Müller Maximilian, “Wer trägt das Pandemierisiko in der Geschäftsraummiete?”, NZM 2020, s. 489.

Hellner Jan, "Pacta sunt servanda - gilt dieser Grundsatz auch für die Miete in Zeiten der COVID-Pandemie?", NJOZ 2020, s. 770.

Hübner Jürgen, Das Gesetz zur Abmilderung der Folgen der COVID-19-Pandemie im Geschäftsraummietrecht - nicht mehr als ein erster Schritt, ZfIR 2020, s. 277 vd.

İleri Çiğdem, “Çevresel Gürültü Nedeniyle Kiraya Verenin Ayıba Karşı Tekeffül Sorumluluğu”, Yıldırım Beyazıt Hukuk Dergisi, Sayı: 1, Ocak 2021, s. 461.

İnceoğlu M. Murat, Kira Hukuku C. 1, İstanbul 2014, On İki Levha Yayıncılık.

Kayış Ferhat, "KOVID-19 (Koronavirüsü) Nedeniyle İşyeri Kira Sözleşmelerinin Yeni Koşullara Uyarlanması”, Yaşar Hukuk Dergisi, Cilt:2, Sayı:2 Özel Sayı, 2020. 
Kılıçoğlu Ahmet, Bulaşıcı Hastalı̆̆ın Borç İlişkilerine Etkisi, Yayımlanmamış Makale https://www. turkhukukkurumu.org.tr/duyurular/377-bulasici-hastaligin-borc-iliskilerine-etkisi.html. (Son Erişim Tarihi: 29.03.2021)

Kluth Peter/ Böckmann Julius, Zugangsbeeinträchtigung aufgrund staatlicher Baumaßnahmen Risikoverteilung bei Gewerberaummiete, NZM 2003, s. 883.

Krepold Hans-Michael, “Gewerbemietverträge in Zeiten der Corona-Pandemie”, WM 2020, s. 728.

Lehmann-Richter Arnold, “Einkaufscenter: Beitritt zu Werbegemeinschaftsverein wirksam!”, MietRB 2016, s. 196.

Makaracı Başak Aslı/ Öktem Çevik Seda/ Yörük Işılay, "Korona Virüsün İşyeri Kira Sözleşmelerine Etkisi”, Yayımlanmamış Makale, Lexpera, https://blog.lexpera.com.tr/koronavirus-tedbirlerinin-kirasozlesmelerine-etkisi/ (Son Erişim Tarihi: 11.05.2021).

Oğuz Arzu, "COVID19, Mücbir Sebep ve sözleşmelere Etkisi”, Terazi Hukuk Dergisi, 2020, Cilt:15, Sayı:166, s. 1275.

Oğuzman Kemal/ Öz Turgut, Borçlar Hukuku Genel Hükümler Cilt I, 18. Baskı 2020.

Özçelik Ş. Barış, "Covid-19 Salgını Çerçevesinde Alınan Önlemlerin Sözleşme Hukuku ve Mücbir Sebep Kavramı Açısından Değerlendirilmesi,” Covid-19 Salgınının Hukuki Boyutu (ed. Muhammet Özekes), İstanbul 2020, On İki Levha Yayıncilık, ss. 283 - 293.

Münchener Kommentar zum Bürgerlichen Gesetzbuch: BGB, Band 5: Schuldrecht - Besonderer Teil II, 8. Auflage 2020, Hrsg. Franz Jürgen Säcker, Roland Rixecker, Hartmut Oetker, Bettina Limper.

Palandt Kommentar zum BGB, 78. Auflage 2018, Hrsg. Otto Palandt.

Sarıkaya Sinan, "Basiretli Tacir İlkesi Işı̆̆ında Koronavirüs (COVID-19) Salgınının Sözleşmelerdeki Ceza Koşuluna Etkisi”, Covid-19 Salgınının Hukuki Boyutu (ed. Muhammet Özekes), İstanbul 2020, On İki Levha Yayıncilık, ss. 629-645.

Schall Alexander, "Corona-Krise: Unmöglichkeit und Wegfall der Geschäftsgrundlage bei gewerblichen Miet und Pachtverträgen", JZ 2020, s. 388.

Schmidt Hubert, COVID-19: Rechtsfragen zur Corona-Krise, 2. Baskı 2020, 3 Rn. 71.

Schmidt-Futterer Mietrecht Kommentar, 14. Auflage 2019, Hrsg. Hubert Blank.

Sentek Stefan/ Ludley Carsten, “COVID-19: Die hoheitlich verfügte Ladenschließung als Mietmangel”, NZM 2020, s. 406.

Sittner Silvio, "Mietrechtspraxis unter Covid-19", NJW 2020, s. 1172.

Tandoğan Haluk, Borçlar Hukuku Özel Borç İlişkileri C.1/2, 4. Baskı, İstanbul 2008, Vedat Kitapçılık.

Toprakkaya Babalık İrem, "Korona Virüs Salgınının Kira Sözleşmelerine Etkisi, Geçici İfa İmkânsızlığı, İfa Güçlügü ve Uyarlama”, Yayımlanmamış Makale, Lexpera, https://blog.lexpera.com.tr/korona-virussalgininin-kira-sozlesmelerine-etkisi-gecici-ifa-imkansizligi-ifa-guclugu-ve-uyarlama-2/ (Son Erişim Tarihi: 11.05.2021).

Tüzüner Özlem/ Öz Kerem, “Aşırı İfa Güçlüğüne İlişkin İçtihat İncelemesi”, Ankara Barosu Dergisi, 2015; Sayı:3, s. 440 .

Üçer Mehmet/ Meriç Nedim, "Kiracının Tacir Olması Durumunda Kiraya Verenin Ayıptan Sorumluluğunun Kapsamı”, Dicle Üniversitesi Hukuk Fakültesi Dergisi, 2014, Cilt: 19, Sayı: 30-31.

Yavuz Cevdet/ Acar Faruk/ Özen Burak, Borçlar Hukuku Dersleri (Özel Hükümler), 16. Baskı, İstanbul 2019, Beta Yayıncilik.

Yıldırım Abdülkerim, "Koronavirüs Krizinin Özel Hukuk Sözleşmelerine Etkisi”, Terazi Hukuk Dergisi, 2020, Cilt:15, Sayı:165, s. 986. 
Yücel Özge, “COVID-19 Salgınının Borç İlişkilerine Hukuksal Etkileri”, Terazi Hukuk Dergisi, Cilt: 15, Sayı. 166, 2020.

Zehner Donata, "Mietrechtliche Neuregelungen in Zeiten der Coronakrise”, JA 2020, s. 489

\section{KISALTMALAR CETVELI}

\begin{tabular}{|c|c|}
\hline Az. & : Aktenzeichen \\
\hline BGB & : Bürgerliches Gesetzbuch \\
\hline BGE & : Entscheidungen des Schweizerischen Bundesgerichts \\
\hline BGH & : Bundesgerichtshof (Alman Federal Mahkemesi) \\
\hline BGHZ & : Entscheidungen des Bundesgerichtshofes in Zivilsachen \\
\hline BK & : Borçlar Kanunu \\
\hline Bkz. & : Bakınız \\
\hline Ed. & : Editör \\
\hline E. & : Esas \\
\hline f. & : Fikra \\
\hline Hrsg. & : Herausgeber \\
\hline $\mathrm{JZ}$ & : JuristenZeitung \\
\hline K. & : Karar \\
\hline Karş. & : Karşılaştırınız \\
\hline LG & : Landesgericht \\
\hline m. & : Madde \\
\hline NJOZ & : Neue Juristische Online-Zeitschrift \\
\hline NJW & : Neue Juristische Wochenschrift \\
\hline NZM & : Neue Zeitschrift für Miet - und Wohnrecht \\
\hline OLG & : Oberlandesgericht \\
\hline TBK & : Türk Borçlar Kanunu \\
\hline TTK & : Türk Ticaret Kanunu \\
\hline RGZ & : Entscheidungen des Reichsgerichts in Zivilsachen. \\
\hline Rn. & : Randnummer \\
\hline s. & : Sayfa \\
\hline ss. & : Sayfa sayısı \\
\hline T. & : Tarih \\
\hline $\mathrm{vd}$. & : Ve devamı \\
\hline
\end{tabular}

